\title{
ANALISIS MANAJEMEN RISIKO PADA KAWASAN TAMAN NASIONAL GUNUNG GEDE PANGRANGO (TNGGP) JAWA BARAT
}

\author{
Suroso \\ Sekolah Tinggi Ilmu Ekonomi Wiyatamandala \\ surosocuk@gmail.com
}

\begin{abstract}
ABTRACT
Tourism has already become major economic contributor since 2014. Many people start to get the experience and explore the world. Base on WTO prediction, there are about 1.6 billion tourists over the world, and most of them are in Asia and Pasific. By 2020 these people could generate about 2 trilion USD income in tourism sector. Indonesia has known as one of biggest archipelago island in the world and has a lot of tourist spot over their island. One of interesting spot in West Java is Taman Nasional Gunung Gede Pangrango in Bogor. This place has been well known as agri-tourism spot for long time ago. Unfortunately in order to increase the competitiveness of this tourist spot, they should implement risk management in their daily operational. We found that the management hasn't implement any risk management in their daily operational. So we would like to conduct some observation and hope can mapping potential risk of this place. Purpose of this research is aim to mapping risk and conducted quadran analysis in order to achieved good risk management of Taman Nasional Gunung Gede Pangrango. And the this tourist spot can be one of unique tourist spot that can support Indonesia Tourism in 2020.
\end{abstract}

Keyword: Tourism; Quadran Analysis; Risk Management; Taman Nasional Gunung Gede Pangrango; Agri-Tourism

\section{PENDAHULUAN}

Pariwisata merupakan industri padat karya yang mampu membuka lapangan kerja, terutama bagi wanita dan kaum muda, membantu memutus siklus kemiskinan melalui pemberdayaan dan peningkatan sumber daya manusia dan penciptaan prospek baru untuk generasi yang akan datang. Pertumbuhan industry pariwisata belakangan ini juga sangat baik dan memberikan peluang yang sangat bagus. Prospek pariwisata ke depan sangat menjanjikan apabila menyimak angkaangka perkiraan jumlah wisatawan internasional (inbound tourism) berdasarkan perkiraan WTO yakni 1,602 milyar orang (tahun 2020), diantaranya masing-masing 231 juta dan 438 juta orang berada di kawasan Asia Timur dan Pasifik, dan akan mampu menciptakan pendapatan dunia sebesar USD 2 triliun pada tahun 2020 .

Berdasarkan angka perkiraan tersebut seyogyanya para pelaku pariwisata Indonesia melakukan perencanaan yang matang dan terarah untuk menjawab tantangan sekaligus menangkap peluang. 
Pemanfaatan peluang harus dilakukan melalui pendekatan "re-positioning " keberadaan masing-masing kegiatan pariwisata dimulai dari sejak investasi, promosi, pembuatan produk pariwisata, penyiapan jaringan pemasaran internasional, dan penyiapan sumber daya manusia yang berkualitas. Kesemuanya itu harus disiapkan untuk memenuhi standar internasional sehingga pariwisata Indonesia lebih kompetitif dan lebih menarik dibandingkan pariwisata negaranegara disekitar Indonesia.

Perkembangan sektor pariwisata sangat prospektif karena selain dapat berperan sebagai salah satu penghasil pertumbuhan ekonomi, sektor pariwisata juga diharapkan untuk dapat menjadi pendorong pertumbuhan sektor pembangunan lainnya, sepertihalnya sektor perdagangan komoditi, perbankan, perindustrian, dan lain-lain. Salah satu unsur dari sektor pariwisata di Indonesia yang saat ini belum tergarap secara optimal adalah agrowisata (agrotourism). Potensi agro wisata Indonesia sangatlah besar karena ditunjang oleh kekayaan dan keragaman bidang pertanian, perikanan, perkebunan, peternakan, dan kehutanan.

Salah satu agrowisata kehutanan yang masih bertahan bahkan berkembang adalah agrowisata pada kawasan Taman Nasional Gunung Gede Pangrango. Pada kawasan ini sudah terlaksana berbagai macam aktivitas kegiatan wisata yang mendukung pada kelestarian alam dan hubungan timbal baliknya kepada masyarakat dan lingkungan sekitar.

Sejalan dengan meningkatnya semangat kembali ke alam dan bertambahnya jumlah penduduk, juga berkembanganya industry di kota-kota besar, maka upaya konservasi melalui taman nasional sebagai agrowisata yang berbasis wisata alam sebagai wahana penelitian, pendidikan dan pengembangan ilmu pengetahun sangat menunjang terhadap budidaya, pariwisata dan rekreasi.

Taman Nasional Gunung Gede Pangarngo (TNGGP) mempunyai posisi yang penting dalam sejarah cagara alam di Indonesia. Taman nasional ini dapat di tempuh dari Jakarta kurang leboh 2.5 jam $(100 \mathrm{~km})$, mempunya luas hutan alam $21.975 \mathrm{Ha}$ yang pada tahun 1982 diresmikan menjadi Taman Nasional di Indonesia. Kawasan TNGGP memiliki kekayaan flora yang tinggi, yaitu sekitar 1000 jenis flora, yang terdiri dari tumbuhan berbunga sebanyak 925 jenis, tumbuhan paku 250 jenis, lumut 123 jenis. Selain flora, TNGGP menyediakan habitat bagi keanekaragaman fauna. Terdapat 251 jenis burung dan 110 jenis mamalia. Selain itu ada juga jenis lutung yang hamper punah, macan tutul, elang jawa dan lain sebagainya.

Sebagaimana layaknya industri yang bergerak di bidang layanan, TNGGP 
sangatlah rentan terhadap risiko. Kemajuan teknologi dewasa ini memungkinkan penyebaran informasi berlangsung setiap saat, 24 jam sehari di seluruh dunia. Terjadinya cacat layanan akibat permasalahan pada produkproduk/layanan yang ditawarkan oleh suatu agrowisata dengan cepat menyebar beritanya melalui media sosial, dan lainlain. Kondisi ini memungkinkan hancurnya reputasi yang dibangun oleh TNGGP dalam hitungan detik, padahal sangat sulit untuk membangun sebuah nama baik. Korbanan untuk membangun sebuah nama yang terpercaya tidak hanya berupa uang, namun juga waktu, pikiran, tenaga, peluang dan sebagainya. Berkembangnya TNGGP menjadikan manajemen risiko makin penting mengingat industri ini sangat bergantung pada kepuasan wisatawan terhadap kualitas layanan yang diterimanya sehubungan dengan produkproduk/layanan yang ditawarkan oleh TNGGP. Dalam hal ini manajemen risiko di TNGGP berperan sangat penting dalam memajukan TNGGP melalui strategi mitigasi risiko yang efektif dan efisien.

Karakteristik TNGGP yang berbeda dari industri lain, secara normatif memunculkan penekanan pengelolaan dan tipologi (klasifikasi) risiko yang khas pula. Untuk mengelola risiko pada TNGGP secara efektif dan efisien, sumber-sumber risiko harus dapat ditelusuri, terutama terkait risiko-risiko dengan dampak signifikan. Dalam hal ini diperlukan masukan yang merupakan hasil upaya yang diperoleh dari hasil inventarisasi, identifikasi berbagai risk event yang muncul maupun yang berpotensi muncul. Untuk TNGGP, risiko operasional dan risiko reputasi lebih memperoleh perhatian dibandingkan risiko kredit karena karakteristik TNGGP yang rentan terhadap ketidakpuasan konsumen pada saat kualitas produk/layanan yang diperoleh konsumen tidak memenuhi standar. Namun demikian sejauh ini belum didapati model manajemen risiko yang secara khusus berlaku untuk TNGGP. Pengelolaan TNGGP yang sejauh ini dijalankan masih belum menyentuh pada aspek manajemen risiko yang sangat berperan penting sehubungan dengan berbagai risk event yang dapat muncul dari produk-produk yang ditawarkan, terutama risiko operasional risiko reputasi dari TNGGP yang bersangkutan. Berdasarkan hal tersebut maka pada kesempatan ini akan diteliti mengenai Analisis Manajemen Risiko di Taman Nasional Gunung Gede Pangarango (TNGGP), Jawa Barat. Berdasarkan latar belakang tersebut, maka perumusan masalah dalam penelitian ini adalah sebagai berikut: 
1. Bagaimana potensi wisata Taman Nasional Gunung Gede Pangarango?

2. Bagaimana Manajemen Risiko di Taan Nasional Gunung Gede Pangarango?

Adapun tujuan dari penelitian ini adalah untuk mengetahui potensi wisata di Taman Nasional Gunung Gede Pangrango dan untuk menganalisis manajemen risiko di Taman Nasional Gunung Gede Pangrango. Diharapkan hasil penelitian ini dapat menambah wawasan serta cara pandang dosen dan mahasiswa dalam memperkaya khazanah ilmu manajemen.

\section{TELAAH LITERATUR}

\section{Risiko}

Risiko menyatakan terjadinya penyimpangan dari target, sasaran, atau harapan, yang berdampak pada kerugian akibat kemungkinan terjadinya hasil yang tidak diinginkan.Risiko dapat menimbulkan kerugian apabila tidak diantisipasi serta tidak dikelola dengan semestinya (Santi Palupi \& Sugiarto, 2014).

Munculnya risiko, dipicu oleh sumber risiko yang berpotensi mendatangkan bencana terhadap komunitas, perusahaan atau organisasi.Dalam hal ini perlu disadari bahwa setiap sumber risiko mengandung bahaya yang berpotensi menyebabkan kerugian dan kehilangan bagi perusahaan, komunitas maupun lingkungan. Pada umumnya, sumbersumber risiko agrowisata dapat dipicu oleh alam, teknologi, biologi, keadaan politik, dll. Pengunjung suatu destinasi agrowisata dapat mengalami kejahatan umum, kebrutalan tindakan dari oknum yang tidak bertanggung jawab, kejahatan terorganisasi, terorisme, konflik social, peperangan, ketidakmampuan aparat keamanan memberikan perlindungan kepada masyarakat, kepada perusahaan hingga kepada publik yang kesemuanya memunculkan risiko. Belum lagi bila wisatawan merasa kecewa karena kualitas sanitasi yang buruk, ketidaktaatan perusahaan dalam merealisasikan kontrak, tidak tersedianya perlindungan yang memadai terhadap tindakan di luar hukum, dll yang juga memunculkan risiko.

\section{Tipologi Risiko}

Sejauh ini belum ditetapkan tipologi risiko yang secara khusus berlaku untuk industri pariwisata \& hospitaliti pada umumnya dan agrowisata pada khususnya. Pada tahap awal penelitian ini akan digunakan tipologi risiko sebagaimana dikemukakan oleh Crouhy, Galai \& Mark (2006), sebagaimana tertera pada Gambar 1 ini. 


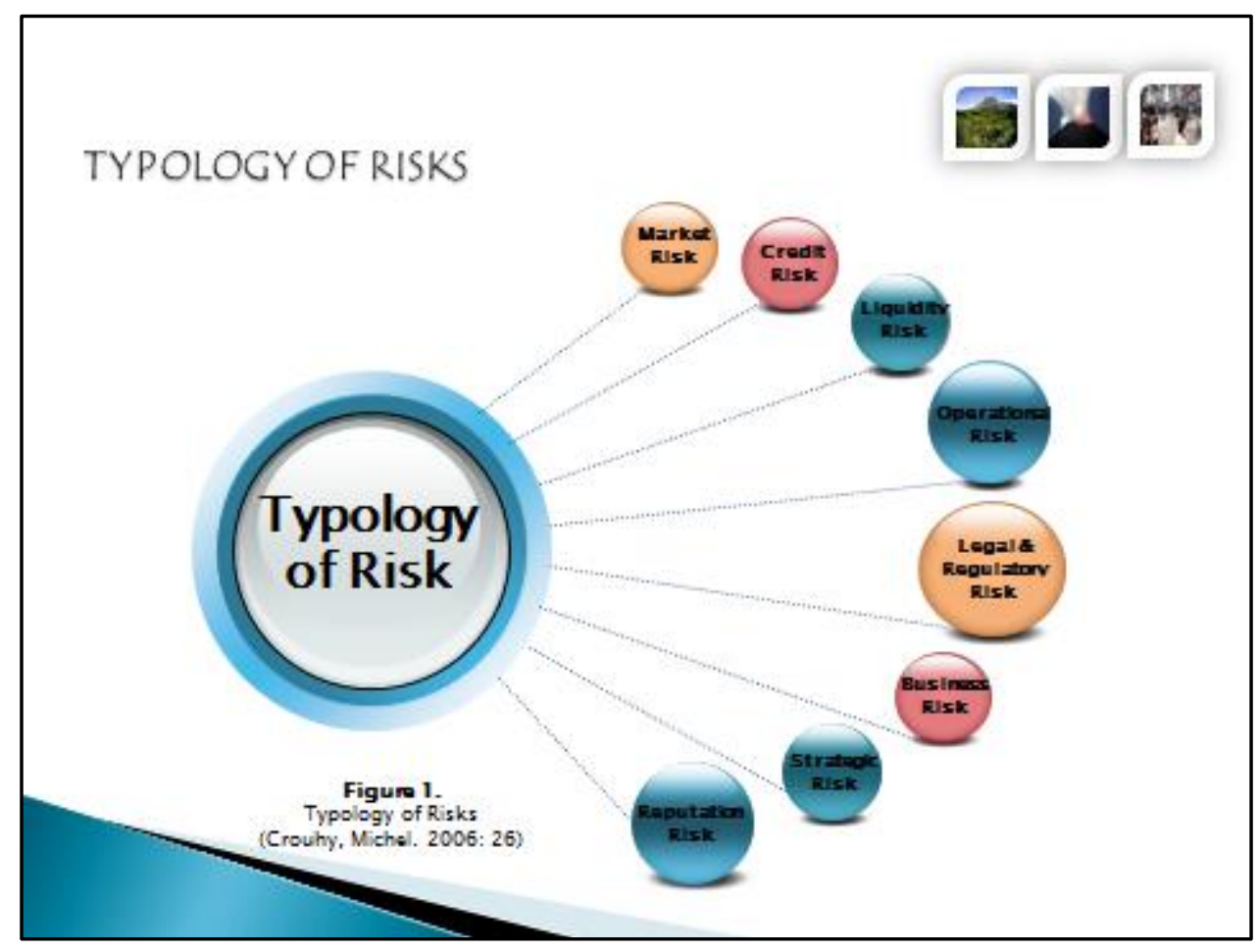

Gambar 1. Tipologi Risiko (Crouhy, Michel, 2006)

Market Risk (Risiko Pasar) merupakan nama yang diberikan terhadap suatu kelompok risiko yang dipicu oleh perubahan suku bunga, nilai tukar dan berkaitan dengan gerak berlawanan dalam nilai pasar suatu aktiva, sepertihalnya saham, obligasi, pinjaman, valas atau komoditas, serta transaksi derivatif yang berkaitan dengan aktiva.

Credit Risk (Risiko Kredit) adalah risiko yang muncul karena debitur atau pembeli secara kredit tidak dapat dan/atau tidak mau membayar utangnya dan memenuhi kewajiban finansial nya sebagaimana yang tertuang dalam kesepakatan pada saat jatuh tempo yang dijanjikan.

Liquidity Risk (Risiko Likuiditas) adalah risiko yang muncul karena perusahaan tidak dapat memenuhi kewajiban pembayaran jangka pendek dan/atau membayar pengeluaran tak terduga. Risiko likuiditas berkaitan dengan pengelolaan modal kerja perusahaan. Risiko ini terjadi bila perusahaan kekurangan uang tunai atau modal kerja bentuk lain yang bisa diuangkan dengan mudah untuk membayar utang dagang, utang pajak, utang bank yang jatuh tempo, commercial paper dan kewajiban jangka pendek lainnya.Risiko likuiditas bisa dipicu oleh kemungkinan penjualan suatu aset perusahaan dengan potongan harga yang besar karena sulitnya mencari pembeli. Kondisi ini terjadi bagi aset-aset yang jarang diperdagangkan.

\section{Operational Risk (Risiko Operasional)} adalah risiko yang ditimbulkan oleh 
ketidakmampuan atau kegagalan proses internal (yaitu sistem dan karyawan) atau adanya kejadian eksternal. Pengertian risiko operasional dapat dibagi menjadi beberapa kategori, yaitu: proses internal, karyawan, sistem, kejadian-kejadian eksternal, persyaratan regulasi dan hukum.

\section{Legal and Regulatory Risk (Risiko}

Hukum) adalah risiko yang ditimbulkan oleh penyimpangan hasil karena perusahaan tidak mematuhi peraturan dan norma yang berlaku.

Business Risk (Risiko Bisnis) adalah risiko yang terkait dengan posisi persaingan dari perusahaan dan prospek perusahaan untuk sejahtera dalam pasar yang berubah. Risiko bisnis meliputi prospek jangka panjang dan jangka pendek bagi produk dan jasa yang ada.

Strategic Risk (Risiko Stratejik) adalah risiko yang diasosiasikan dengan keputusan bisnis jangka panjang yang dibuat oleh manajemen senior. Risiko ini diakibatkan keputusan strategis yang tidak sesuai dengan lingkungan eksternal dan internal usaha.Risiko stratejik berhubungan dengan pengambilan keputusan seperti halnya:di bisnis mana perusahaan mau berinvestasi, bisnis mana yang akan diakuisisi, dimana dan bisnis apa yang kinerjanya akan menurun atau akan dijual.

Reputation risk (Risiko Reputasi) adalah risiko kerusakan potensial pada suatu perusahaan yang dihasilkan dari opini publik yang negatif. Risiko reputasi berpotensi menghilangkan atau menghancurkan nama baik perusahaan, penerimaan lingkungan eksternal yang rendah, bahkan bisa mengakibatkan penolakan terhadap perusahaan. Penyebab penolakan tersebut dapat dipicu oleh ketidakmampuan perusahaan mengambil tindakan terhadap isu eksternal yang terkait dengan perusahaan dan ketidakmampuan perusahaan mengelola komunikasi dengan pihak eksternal yang berkepentingan yang dapat menimbulkan persepsi buruk terhadap perusahaan.

\section{Manajemen Risiko}

Pada hakekatnya manajemen risiko bertujuan untuk mengelola risiko yang dihadapi oleh perusahaan dan memitigasi (mereduksi) dampakyang terjadi. Prinsip dasar yang digunakan dalam manajemen risiko merujuk pada tujuan pengelolaan perusahaan pada umumnya, yaitu memaksimalkan nilai perusahaan dan kekayaan pemegang saham, yang pada prinsipnya adalah ekspektasi kinerja masa depan perusahaan.

Ekspektasi kinerja masa depan perusahaan terkait erat dengan ekspektasi arus kas dan tingkat risiko yang menentukan nilai perusahaan. Nilai sekarang perusahaan dapat diperoleh menggunakan persamaan untuk menghitung present value, sebagai berikut: 


$$
P V=\frac{F V_{n}}{(1+k)^{n}}=F V_{n} \cdot\left[\frac{1}{(1+k)^{n}}\right]
$$

Dalam hal ini:

- $\mathrm{PV}=$ present value atau nilai pokok

- $\mathrm{FVn}=$ future value pada akhir periode $\mathrm{n}$

- $\mathrm{k}=$ tingkat pengembalian

- $\mathrm{n}=$ banyaknya periode pemajemukan

Dalam persamaan di atas, ekspektasi arus kas dan tingkat risiko merupakan variabel yang menjadi pusat terbentuknya nilai dan kekayaan. Semakin tinggi ekspektasi arus kas yang bisa dihasilkan perusahaan, semakin tinggi nilai dan kekayaan. Ekspektasi arus kas yang bisa dihasilkan perusahaan, tercermin pada komponen $F V_{n}$. Dalam hal ini besarnya komponen $F V_{n} \quad$ berbanding lurus dengan nilai perusahaan. Dengan demikian semakin tinggi ekspektasi arus kas yang bisa dihasilkan perusahaan, semakin tinggi nilai dan kekayaan perusahaan.Besarnya tingkat risiko direpresentasikan oleh huruf $\mathrm{k}$ dalam komponen $\left[\frac{1}{(1+k)^{n}}\right]$. Dalam hal ini besarnya komponen kmenyatakan tingkat pengembalian dari suatu investasi.Tingkat pengembalian yang ditetapkan telah mempertimbangkan unsur risiko investasi (yang dilambangkan dengan r). Dalam hal ini nilai $\mathrm{k}$ adalah nilai $\mathrm{r}$ ditambah dengan besaran tertentu yang ditargetkan. Dengan demikian karena nilai $\mathrm{k}$ dalam rumus tersebut berkontribusi dalam komponen pembagi, maka besarnya nilai $\mathrm{k}$ berbanding terbalik dengan nilai perusahaan. Dengan semakin tinggi risiko maka semakin tinggi nilai $\mathrm{k}$, dengan konsekuensi semakin rendah nilai perusahaan dan demikian juga kekayaan pemegang saham.Karena itu risiko harus dapat dikelola sehingga risiko dapat diturunkan, dan pada akhirnya nilai perusahaan akan makin tinggi.

Untuk meningkatkan nilai perusahaan, dapat ditempuh tiga cara berikut:

1. meningkatkan arus kas masuk, dengan menjaga tingkat risiko tetap pada besaran tertentu

2. menurunkan risiko, dengan menjaga arus kas tetap pada besaran tertentu

3. meningkatkan arus kas dan secara simultan menurunkan risiko.

Pada kondisi perusahaan mengalami kesulitan untuk meningkatkan arus kas masuk, maka menurunkan risiko merupakan alternatif yang dapat 
meningkatkan nilai perusahaan. Dalam hal ini manajemen risiko merupakan media yang dapat digunakan untuk mengelola risiko. Pada prinsipnya selama biaya total pengelolaan risiko masih lebih rendah dari manfaat yang diperoleh, maka manajemen risiko berguna bagi pencapaian tujuan perusahaan.

\section{AGRIWISATA}

Agriwisata atau agrowisata adalah istilah yang mengacu pada pariwisata berbasis pertanian. Kedua istilah ini sama sekali tidak mengandung perbedaan makna hanya lebih pada preferensei penyebutan. Konsep agriwisata merupakan perluasan langsung dari konsep ekowisata yang mendorong atau mengajak para wisatawan untuk mendapatkan pengalaman dalam kegiatan dan kehidupan dan bertani secara langsung. Agriwisata sangat bermanfaat bagi peningkatan kualitas hidup para petani, karena para petani akan memperoleh pendapatan dari aktivitas bertani mereka.

Dalam istilah sederhana, agritourism didefinisikan sebagai perpaduan antara pariwisata dan pertanian dimana pengunjung dapat mengunjungi kebun, peternakan atau kilang anggur untuk membeli produk, menikmati pertunjukan, mengambil bagian aktivitas, makan suatu makanan atau melewatkan malam bersama di suatu areal perkebunan atau taman. Sementara definisi lain mengatakan bahwa agritourism adalah sebuah alternatif untuk meningkatkan pendapatan dan kelangsungan hidup, menggali potensi ekonomi petani kecil dan masyarakat pedesaan.

Di Indonesia, Agrowisata didefinisikan sebagai sebuah bentuk kegiatan pariwisata yang memanfaatkan usaha agro (agribisnis) sebagai objek wisata dengan tujuan untuk memperluas pengetahuan, pengalaman, rekreasi dan hubungan usaha di bidang pertanian. Agrowisata merupakan bagian dari objek wisata yang memanfaatkan usaha pertanian (agro) sebagai objek wisata. Tujuannya adalah untuk memperluas pengetahuan, pengalaman rekreasi, dan hubungan usaha dibidang pertanian. Melalui pengembangan agrowisata yang menonjolkan budaya lokal dalam memanfaatkan lahan, diharapkan bisa meningkatkan pendapatan petani sambil melestarikan sumber daya lahan, serta memelihara budaya maupun teknologi lokal (indigenous knowledge) yang umumnya telah sesuai dengan kondisi lingkungan alaminya.

Agrowisata dapat dikelompokkan ke dalam wisata ekologi (eco-tourism), yaitu kegiatan perjalanan wisata dengan tidak merusak atau mencemari alam dengan tujuan untuk mengagumi dan menikmati keindahan alam, hewan atau tumbuhan liar 
di lingkungan alaminya serta sebagai sarana pendidikan (Deptan, 2005).

Antara ecotourism dan agritourism berpegang pada prinsip yang sama yaitu (Wood, 2000):

1. Menekankan serendah-rendahnya dampak negatif terhadap alam dan kebudayaan yang dapat merusak daerah tujuan wisata;

2. Memberikan pembelajaran kepada wisatawan mengenai pentingnya suatu pelestarian alam;

3. Menekankan pentingnya bisnis yang bertanggung jawab yang bekerjasama dengan unsur pemerintah dan masyarakat untuk memenuhi kebutuhan penduduk lokal dan memberikan manfaat pada usaha pelestarian;

4. Mengarahkan keuntungan ekonomi secara langsung untuk tujuan pelestarian, menejemen sumber daya alam dan kawasan yang dilindungi;

5. Memberi penekanan pada kebutuhan zone pariwisata regional dan penataan serta pengelolaan tanam-tanaman untuk tujuan wisata di kawasan-kawasan yang ditetapkan untuk tujuan wisata tersebut;

6. Memberikan penekanan pada kegunaan studi-studi berbasiskan lingkungan dan sosial, dan program-program jangka panjang untuk mengevaluasi dan menekan serendah-rendahnya dampak pariwisata terhadap lingkungan;

7. Mendorong usaha peningkatan manfaat ekonomi untuk negara, pebisnis, dan masyarakat lokal, terutama penduduk yang tinggal di wilayah sekitar kawasan yang dilindungi;

8. Berusaha untuk meyakinkan bahwa perkembangan pariwisata tidak melampaui batas-batas sosial dan lingkungan yang dapat diterima seperti yang ditetapkan para peneliti yang telah bekerjasama dengan penduduk lokal;

9. Mempercayakan pemanfaatan sumber energi, melindungi tumbuh-tumbuhan dan binatang liar, dan menyesuaikannya dengan lingkungan alam dan budaya;

Di beberapa negara, agritourism bertumbuh sangat pesat dan menjadi alternatif terbaik bagi wisatawan, hal ini disebabkan karena agritourism akan membawa seseorang mendapatkan pengalaman yang benar-benar berbeda dari rutinitas kesehariannya. Mereka ingin keluar dari kejenuhan, tekanan kemacetan lalulintas, telepon selular, suasana kantor dan hiruk pikuk keramaian. Orang tua ingin anak-anak mereka dapat mengetahui dari mana sebenarnya makanan itu berasal 
atau mengenalkan bahwa susu itu dari seekor sapi bukan rak supermarket.

Pada era ini, manusia hidupnya sangat dipenuhi dengan kejenuhan, rutinitas dan berbagai kesibukan. Untuk kedepannya, prospek pengembangan agrowisata diperkirakan sangat cerah. Pengembangan agrowisata itu sendiri dapat diarahkan dalam bentuk ruangan tertutup (seperti museum), ruangan terbuka (taman atau lanskap), atau kombinasi antara keduanya. Agrowisata ruangan tertutup dapat berupa koleksi alat-alat pertanian yang khas dan bernilai sejarah, sejarah penggunaan lahan maupun proses pengolahan hasil pertanian. Sedangkan untuk agrowisata ruangan terbuka dapat berupa penataan lahan yang khas dan sesuai dengan kapabilitas dan tipologi lahan untuk mendukung suatu sistem usaha tani yang efektif dan berkelanjutan. Komponen utama pengembangan agrowisata ruangan terbuka dapat berupa flora dan fauna yang dibudidayakan maupun liar, teknologi budi daya dan pasca panen komoditas pertanian yang khas dan bernilai sejarah, atraksi budaya pertanian setempat, dan pemandangan alam berlatar belakang pertanian dengan kenyamanan yang dapat dirasakan. Agrowisata ruangan terbuka dapat dilakukan dalam dua versi/pola, yaitu alami dan buatan (http://database.deptan.go.id).
Selanjutnya agrowisata ruangan terbuka dapat dikembangkan dalam dua versi/pola, yaitu alami dan buatan, yang dapat dirinci sebagai berikut:

\section{Agrowisata Ruang Terbuka Alami}

Objek agrowisata ruangan terbuka alami ini berada pada areal di mana kegiatan tersebut dilakukan langsung oleh masyarakat petani setempat sesuai dengan kehidupan keseharian mereka. Masyarakat melakukan kegiatannya sesuai dengan apa yang biasa mereka lakukan tanpa ada pengaturan dari pihak lain. Untuk memberikan tambahan kenikmatan kepada wisatawan, atraksi-atraksi spesifik yang dilakukan oleh masyarakat dapat lebih ditonjolkan, namun tetap menjaga nilai estetika alaminya. Sementara fasilitas pendukung untuk kenyamanan wisatawan tetap disediakan sejauh tidak bertentangan dengan kondisi/adat masyarakat yang ada, seperti sarana transportasi, tempat berteduh, sanitasi, dan keamanan dari binatang buas. Contoh agrowisata terbuka alami adalah kawasan Suku Baduy di Banten dan Suku Naga di Tasikmalaya Jawa Barat; Suku Tengger di Jawa Timur, Bali dengan teknologi subaknya, dan Papua dengan berbagai pola atraksi pengelolaan lahan untuk budi daya umbiumbian.

\section{Agrowisata Ruang Terbuka Buatan}

Kawasan agrowisata ruang terbuka buatan ini dapat didesain pada kawasan-kawasan 
yang spesifik, namun belum dikuasai atau disentuh oleh masyarakat adat. Tata ruang peruntukan lahan diatur sesuai dengan daya dukungnya dan komoditas pertanian yang dikembangkan memiliki nilai jual untuk wisatawan. Demikian pula teknologi yang diterapkan diambil dari budaya masyarakat lokal yang ada, diramu sedemikian rupa sehingga dapat menghasilkan produk atraksi agrowisata yang menarik. Fasilitas pendukung untuk akomodasi wisatawan dapat disediakan sesuai dengan kebutuhan masyarakat modern, namun tidak mengganggu keseimbangan ekosistem yang ada. Kegiatan wisata ini dapat dikelola oleh suatu badan usaha, sedang pelaksana atraksi tetap dilakukan oleh petani lokal yang memiliki teknologi yang diterapkan.

\section{EKOWISATA}

Di dalam penyusunan rencana pengembangan Ekowisata, diawali dengan melakukan identifikasi permasalahan, kebijakan yang dilaksanakan berdasarkan regulasi yang ada dan paradigma yang berkembang. Regulasi secara nasional berkait dengan Ekowisata meliputi peraturan perundangan sebagai berikut:

1. Undang-undang No. 5 Tahun 1990 tentang Konservasi Sumber Daya Alam Hayati dan Ekosistem

2. Undang-undang No. 3 Tahun 1997 Tentang Pengelolaan Lingkungan Hidup
3. Undang-undang No. 41 Tahun 1999 Tentang Kehutanan

4. Undang-Undang No. 26 tahun 2007 Tentang Penataan Ruang

5. Peraturan Pemerintah No. 18 tahun 1994 Tentang Pengusahaan Pariwisata Alam Di Zona Pemanfaatan Taman Nasional, Taman Hutan Raya, Dan Taman Wisata Alam

6. Peraturan Pemerintah No. 68 Tahun 1998 tentang Kawasan Suaka Alam dan Kawasan Pelestarian Alam

7. Peraturan Pemerintah No. 27 Tahun 1999 Tental Analisis Mengenai dampak Lingkungan

8. Peraturan Pemerintah No. 34 Tahun 2002 Tentang Tata Hutan dan Penyusunan Rencana Pengelolaan Hutan, Pemanfaatan Hutan dan Penggunaan Kawasan Hutan.

9. Keputusan Presiden No. 32 tahun 1990 Tentang Pengelolaan Kawasan Lindung

\section{Kerangka Pemikiran}

Untuk memudahkan dalam melaksanakan penelitian mengenai Manjemen Risiko di Taman Nasional Gunung Gede Pangaro maka disusun kerangka pemikiran sebagai berikut: 
Manajemen Risiko

1. Market Risk

2. Credit Risk

3. Liquidity Risk

4. Operational Risk

5. Legal \& Regulatory Risk

6. Business Risk

7. Strategi Risk

8. Reputation Risk

AMAN NASIONAL

GUNUNG GEDE PANGRANGO

Gambar 2. Kerangka Pemikiran Penelitian

\section{METODOLOGI PENELITIAN}

Metode penelitian yang digunakan adalah metode deskriptif. Menurut Kusmayadi dan Sugiarto (2000:29) pengertian dari metode penelitian deskriptif adalah: "Penelitian yang berusaha mendeskriptifkan atau manggambarkan atau melukiskan fenomena atau hubungan antar-fenomena yang diteliti dengan sistematis, faktual, dan akurat."

Unit analisis adalah unit yang diamati adalah manajemen Taman Nasional Gunung Gede Pangarango dengan segala aktivitas wisatanya. Lokasi dan Waktu Penelitian akan dilakukan di Taman Nasional Gunung Gede Pangari selama 6 bulan efektif dari Bulan Juni sampai dengan Bulan November 2017. Penelitian diawali dengan pengumpulan data. Data yang diperoleh selanjutnya dianalisis typology risk serta analisis potensi dengan konsep attraction, aksessibitas dan amenitas. Data yang dibutuhkan terdiri dari data primer dan data sekunder. Data primer diperoleh melalui pengisian kuesioner dan yang disertai dengan wawancara langsung dari nara sumber

Komponen utama dari kuesioner yang diajukan yakni :

1. identifikasi potensi wisata (atrcation, amenitas dan aksessibilitas)

2. identifikasi wisatawan yang berkunjung

3. identifikasi manajemen risiko Sedangkan data sekunder diperoleh melalui bahan publikasi yang diterbitkan oleh instansi terkait dan berhubungan langsung dengan studi ini. Supranto (2000:23) menjelaskan, “Apabila metode pengumpulan data sudah ditemukan, kemudian ditentukkan alat untuk memperoleh data dari objek yang diteliti”. Alat untuk memperoleh keterangan dari objek atau elemen antara lain :

Daftar pertanyaan / suara angket (kuesioner)

1. Wawancara 
2. Observasi atau pengamatan langsung

3. Melalui internet, telepon, atau alat komunikasi lainnya.

Prosedur pengumpulan data yang digunakan dalam penelitian ini melalui dua cara, yaitu :

Data primer diperoleh melalui pengisian kuesioner dan yang disertai dengan wawancara langsung dari nara sumber yang antara terdiri dari atas :Pengelola TNGGP (Dinas Pariwisata Kabupaten, Dinas Perhutanan), Masyarakat Sekitar, dan Wisatawan. Data Sekunder yaitu data yang dari luar perusahaan yang berhubungan dengan objek penelitian dan bersifat menunjang teori. Data tersebut diperoleh dari literatur dan buku-buku teori pendukung sebagai pelengkap data primer. Objek penelitian untuk penelitian ini adalah Tanaman Nasional Gunung Gede Pangrango (TNGGP) seluruh keterangan yang didapat dari TNGGP ini menjadi bahan penulisan.

Pertama-tama data akan diuji Validitas dan Reliabilitasnya. Uji validitas digunakan untuk menunjukkan sejauh mana alat ukur yang digunakan dalam penelitian ini mengukur apa yang ingin diukur. Dengan uji validitas dilakukan pemeriksaan apakah item-item yang dieksplorasi dalam penelitian ini mendukung item total atau tidak. Instrumen penelitian yang digunakan dalam penelitian ini dianggap valid jika informasi yang ada pada tiap item berkorelasi erat dengan informasi dari item-item tersebut sebagai satu kesatuan. Oleh karenanya dalam uji validitas ini digunakan korelasi product moment dengan mengkorelasikan data pada masing-masing pernyataan terhadap skor total. Uji reliabilitas digunakan untuk menguji konsistensi, akurasi dan prediktabilitas alat ukur yang digunakan dalam penelitian ini. Uji reliabilitas data dalam penelitian ini akan mengungkap apakah instrumen yang digunakan merupakan instrumen yang dapat dipercaya (terandal) sebagai alat pengumpul data serta mampu mengungkap informasi yang sebenarnya di lapang. Metode Cronbach's Alpha akan digunakan untuk menguji reliabilitas data. Dengan menggunakan metode Cronbach's Alpha, construct dianggap reliabel bila koefisien Alphanya > 0.70 (Nunnaly, Jum C, 1978).

\section{Importance Performance Analysis}

Setelah tahapan identifikasi risk event, atas dasar perbandingan antara kinerja layanan dan tingkat kepentingan pengunjung/wisatawan terhadap kualitas layanan yang diterimanya, akan dilakukan Importance Performance Analysis.

Pada dasarnya Importance Performance Analysis memberi perhatian yang besar kepada pengguna untuk memberi masukan akan layanan mana saja yang kualitas 
penyampaiannya belum berkenan sesuai harapan mereka. Pemberian penilaian pengguna didasarkan atas dua hal, yaitu terkait kualitas penyampaian jasa yang mereka terima dan rasakan, yang dalam hal ini merepresentasikan kinerja (performance) dari TNGGP, dibandingkan standar kepentingan pengguna sehubungan dengan layanan yang mereka terima yang dalam hal ini merepresentasikan tingkat kepentingan (importance). Selanjutnya terhadap penilaian untuk setiap layanan akan dilakukan pembandingan yang pada intinya untuk mengetahui apakah kinerja setiap layanan yang diberikan oleh TNGGP mampu menjawab tingkat kepentingan dari pengguna. Secara rasional, kepuasan pengguna tercapai saat standar mereka mampu dipenuhi oleh TNGGP, yang berarti kinerja layanan dari TNGGP lebih tinggi dari standar yang ditetapkan oleh pengguna. Perhatian akan diberikan pada produk-produk/layanan dengan kinerja yang belum mampu menjawab tingkat kepentingan pengunjung/wisatawan TNGGP.

Pada tahap berikutnya terhadap berbagai risk event dari setiap produk/layanan TNGGP yang memperoleh perhatian tersebut akan dibedakan lagi menurut dua faktor, yaitu frekuensi dan dampak. Frekuensi menyatakan tingkat keseringan terjadinya suatu peristiwa. Dampak menyatakan besarnya kerugian yang dihasilkan dari suatu peristiwa. Kategori peristiwa risiko operasional tergantung pada keseringan munculnya peristiwa risiko operasional dan tingkat keparahan dari dampaknya. Kombinasi dari frekuensi dan dampak dari suatu peristiwa risiko adalah:

1. Frekuensi rendah/dampak rendah

2. Frekuensi rendah/dampak tinggi

3. Frekuensi tinggi/dampak rendah

4. Frekuensi tinggi/dampak tinggi

Secara umum, manajemen risiko TNGGP memfokuskan hanya pada dua jenis peristiwa ini:

Frekuensi rendah/dampak tinggi dan Frekuensi tinggi/dampak rendah.

\section{HASIL \& ANALISIS}

\section{Analisis Deskriptif}

Survey telah dilakukan ke beberapa tempat wisata di Provinsi Jawa Barat mencakup kawasan wisata Taman Nasional Gunung Gede Pangrango, Taman Nasional Cibodas serta beberapa lokasi rekreasi seperti Curug Cibeureum. Survey dilaksanakan 2x pada tanggal 25 - 26 Juli 2017 dan 25 - 26 Agustus 2017 dengan total tim survey yang dilaksanakan oleh 12 orang. Hasil yang diharapkan dari Survey ini adalah pemetaan Risiko dan Analisis Kuadran dari Kawasan Wisata Taman Nasional Gunung Gede Pangrango.

Kami memetakan peta risiko berdasarkan hasil pengamatan dari tim survey dan 
membagikan kuisioner kepada beberapa pengunjung yang tersebar di kawasan tersebut. Adapun total kuisioner atau tabel pengamatan yang berhasil kami peroleh adalah 30 untuk Taman Cibodas dan 30 untuk Air Terjun Cibeureum, Taman Nasional Gunung Gede Pangrango. Kuadran Risiko dipetakan berdasarkan Aspek Risiko yang telah kami turunkan dari Sapta Pesona. Indikator risiko kami hitung dari skala 1 untuk nilai minimum dan skala 5 untuk nilai maksimum. Masing-masing responden mengukur nilai indikator risiko sebanyak 2 aspek yakni aspek Performance dan aspek Importance. Sehingga hasil yang diperoleh adalah 4 Kuadran risiko yang dibagi berdasarkan nilai rata-rata hasil survey. Berikut ini adalah Indikator Risiko yang diukur dalam penelitian ini yang diperoleh dari Sapta Pesona:

Tabel 1. Indikator Sapta Pesona

\begin{tabular}{|c|c|}
\hline Aspek Sapta Pesona & Indikator Risiko Operasional \\
\hline \multirow{6}{*}{ Aman } & Pos Informasi \\
\hline & Keamanan Lingkungan \\
\hline & Ketersediaan Informasi \\
\hline & Pengetahuan Petugas \\
\hline & Kualitas TK \\
\hline & Kecukupan Petugas \\
\hline \multirow{4}{*}{ Aman } & Poliklinik \\
\hline & Dokter Jaga \\
\hline & Rumah Sakit \\
\hline & Informasi Publikasi \\
\hline \multirow{2}{*}{ Kenangan } & Keterawatan Infrastruktur \\
\hline & Kehandalan Wifi \\
\hline \multirow{2}{*}{ Bersih } & Toilet \\
\hline & Fasilitas Umum \\
\hline \multirow{7}{*}{ Aman } & Signage \\
\hline & Papan Informasi \\
\hline & Jogging Track \\
\hline & Jalan \\
\hline & Tempat Parkir \\
\hline & Aksesibilitas \\
\hline & Fasilitas diakses Online \\
\hline \multirow{3}{*}{ Sejuk } & Ruangan Ber AC \\
\hline & Lingkungan Rindang \\
\hline & Pepohonan Rindang \\
\hline \multirow{2}{*}{ Indah } & Penataan Infrastruktur \\
\hline & Penataan Lingkungan \\
\hline \multirow{2}{*}{ Tertib } & Antrian Masuk \\
\hline & Pedagang Kaki Lima \\
\hline Kenangan & Pelayanan yang Sigap \\
\hline
\end{tabular}




\begin{tabular}{ll}
\hline Aspek Sapta Pesona & Indikator Risiko Operasional \\
\hline & Pelayanan yang Membantu \\
& Kotak Saran \\
& Innovasi Pengelola \\
& Fasilitas Umum \\
& Kepekaan Petugas \\
Ramah & Informasi Promosi \\
Aman & Tenaga Kerja \\
Ramah & \\
\hline
\end{tabular}

Dalam menganalisis Performance - Importance analysis, penelitian ini membagi kuadran menjadi 4 sektor sebagai berikut:

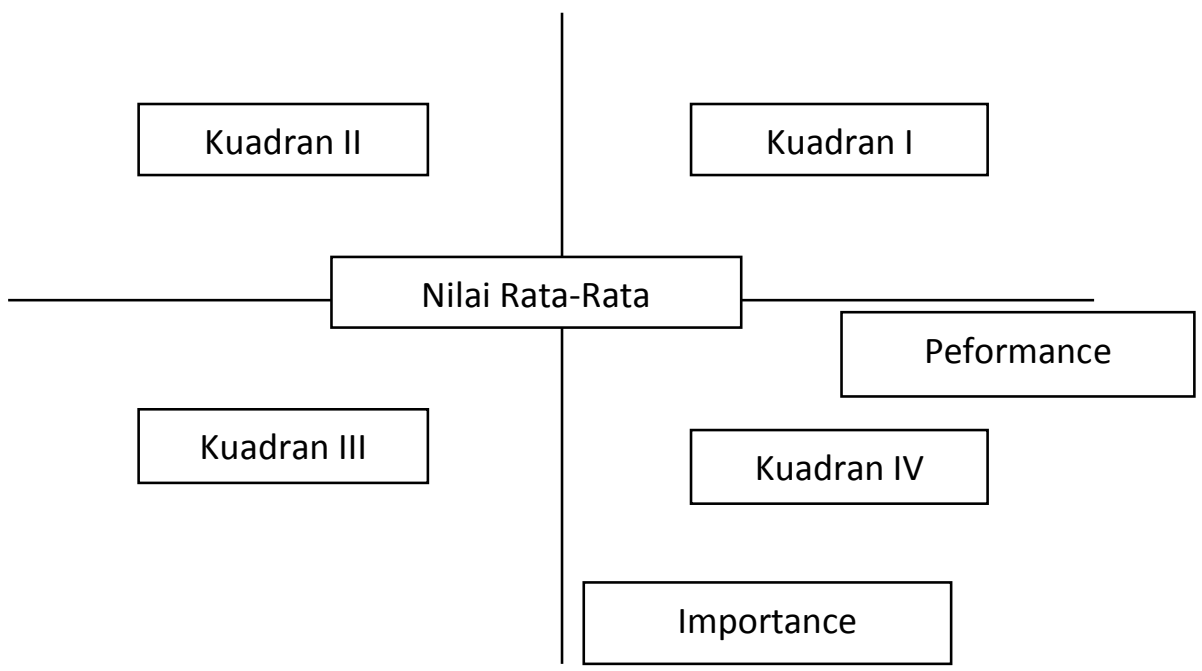

Gambar 3. Analisis Kuadran - Perfomance \& Importance

Pada kuadran I, hasil survey menunjukan performa dan kepentingan dari indikator risiko sudah memenuhi ekspektasi para pengunjung. Hasil pada kuadran 1 harus tetap dipertahankan dan dijaga performanya. Pada kuadran II adalah hasil yang perlu diperhatikan dengan sangat baik oleh pihak pengelola. Hasil pada kuadran II ini menunjukan pentingnya peningkatan performa pada indikator risiko karena masih belum memenuhi ekspektasi para pengunjung. Dari aspek kepetingan, berdasarkan survey hasil pada kuadran II ini patut mendapat perhatian karena menurut pengunjung indikator ini penting dalam kegiatan operasional. Pada kuadran III tingkat kepentingan dari kuadran III sangat rendah dan performa dari kuadran ini juga rendah. Setiap indikator risiko pada kuadran ini menunjukan bagi pengunjung, aspek manajemen risiko disini kurang terlalu penting untuk mendapatkan perhatian pengembangan oleh para pengelola sehingga pengelola bisa fokus pada pengembangan performa pada kuadran II. 
Pada kuadran IV menunjukan terjadinya overperformance yakni tingkat kepetingan dari indikator risiko itu cenderung kecil dan dibawah rata-rata, akan tetapi performanya sangat tinggi. Oleh karena itu alokasi biaya yang ada pada kuadarn IV, bisa dialokasikan kepada kuadran II sehingga bisa terjadi peningkatan performa pada kuadran yang dianggap penting.

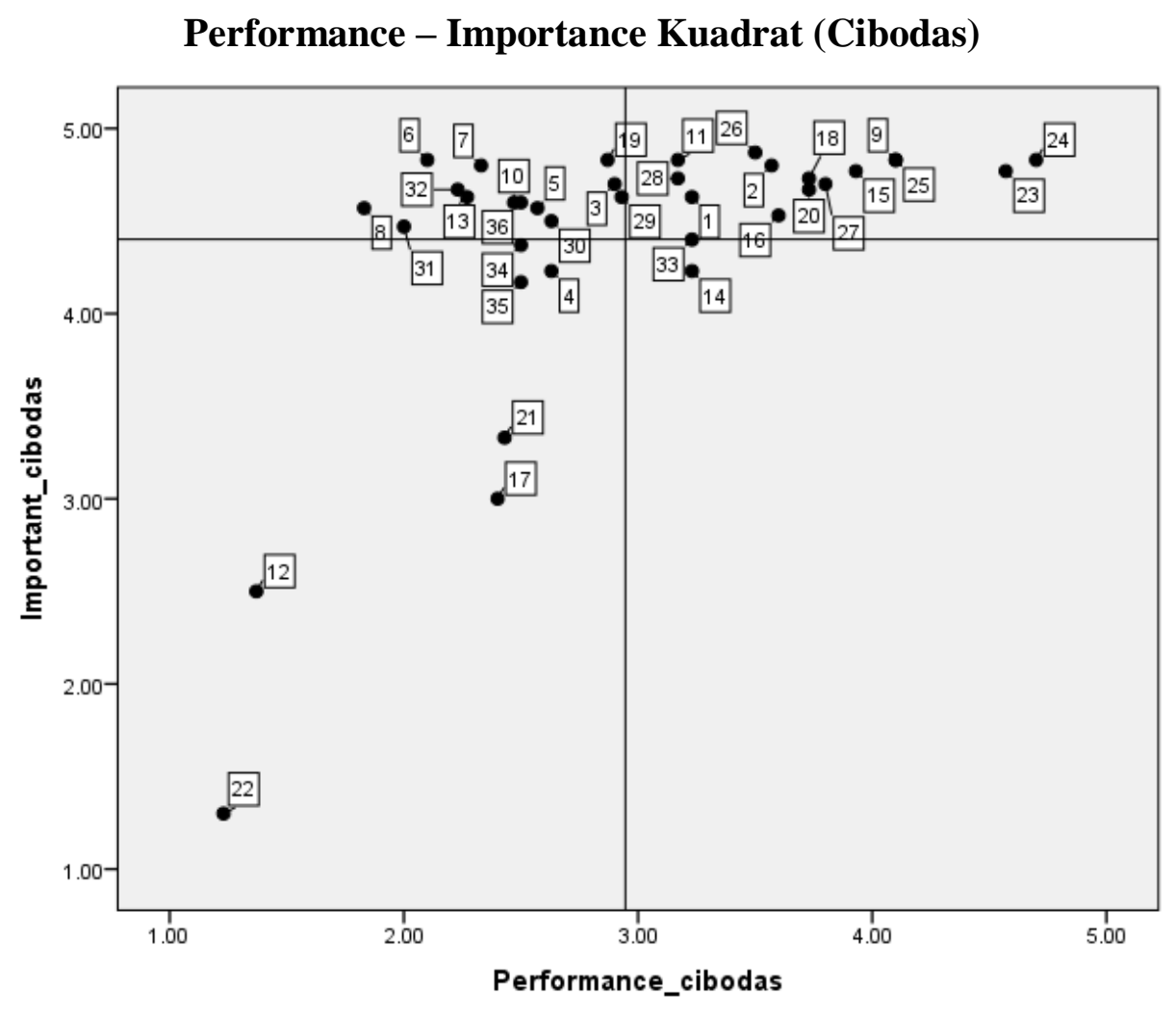

Gambar 4. Kuadran Risiko Untuk Taman Nasional Cibodas

Berdasarkan hasil dari Gambar di atas dan pada tabel 5.2 di bawah terdapat beberapa aspek yang perlu diperhatikan oleh manajemen Taman Cibodas terkait dengan manajemen risiko operasional tempat wisata tersebut.

Peneliti dan tim survey telah melakukan pengamatan langsung dari lokasi. Adapun berikut ini adalah temuan observasi dan catatan yang dirangkum oleh tim survey dari lokasi Taman Cibodas. Dari sisi kualitas kebersihan lingkungan, masih terdapat beberapa sampah yang tidak dikelola dengan baik. Terutama untuk dari tempat buang air kecil dan buang air besar, ditemukan beberapa bekas yang tidak tersiram dengan sempurna. Tim survey juga cukup kesulitan dalam mencari toilet di lahan taman Cibodas yang sangat luas. Perlu pembangunan toilet serta manajemen kebersihan yang lebih baik lagi.

Untuk sisi sumber daya manusia, tidak adanya seragam yang baik bagi para petugas yang berjaga terutama di toilet. 
Pihak pengelola harusnya mempersiapkan seragam khusus bagi para petugas sehingga para pengunjung dapat dengan mudah mengenali petugas dan juga dapat menambah wibawa petugas jika ternyata petugas perlu menegur pengunjung yang tidak tertib. Khususnya untuk para penjual makanan dan minuman di dalam area Cibodas. Harga cenderung dibuat tidak standard sesuai dengan keinginan si penjual. Pihak pengelola hendak membuat koperasi untuk warga setempat yang ingin berjualan sehingga dapat terorganisir dan dapat menjadi lebih manageable. Taman Cibodas ini sendiri memiliki ruang terbuka hijau yang sangat luas, oleh karena itu sangat cocok untuk kegiatan yang sifatnya piknik dan kegiatan fisik atau kegiatan di luar ruangan. Akan tetapi jika digunakan untuk kegiatan yang hanya duduk-duduk saja peneliti rasa kurang cocok. Jika memang cuaca sangat panas, maka masih kurang tempat untuk berteduh sehingga para pengunjung akan terkena cahaya matahari langsung. Sekalipun memang hawa di Taman Cibodas sejuk, akan tetapi tanpa sadar pengunjung yang terus berjemur akan tiba-tiba gosong tanpa merasa kepanasan.

Tabel.2. Indikator Risiko Operasional

\begin{tabular}{|c|c|c|c|c|c|c|}
\hline Risk Operasional Event & $\begin{array}{l}\text { Rata-Rata } \\
\text { Performance }\end{array}$ & $\begin{array}{l}\text { Rata-Rata } \\
\text { Importance }\end{array}$ & $\begin{array}{l}\text { Zona } \\
1\end{array}$ & $\begin{array}{l}\text { Zona } \\
2\end{array}$ & $\begin{array}{l}\text { Zona } \\
3\end{array}$ & $\begin{array}{l}\text { Zona } \\
4\end{array}$ \\
\hline Pos Informasi & 3.23 & 4.63 & $\mathrm{O}$ & - & - & - \\
\hline $\begin{array}{l}\text { Keamanan Lingkungan } \\
\text { wisata }\end{array}$ & 3.57 & 4.80 & $\mathrm{O}$ & - & - & - \\
\hline Ketersediaan Informasi & 2.90 & 4.70 & - & $\mathrm{O}$ & - & - \\
\hline $\begin{array}{l}\text { Pengetahuan Petugas } \\
\text { akan Lokasi Wisata }\end{array}$ & 2.63 & 4.23 & - & - & $\mathrm{O}$ & - \\
\hline Kualitas tenaga kerja & 2.57 & 4.57 & - & $\mathrm{O}$ & - & - \\
\hline $\begin{array}{l}\text { Kecukupan jumlah } \\
\text { petugas }\end{array}$ & 2.10 & 4.83 & - & $\mathrm{O}$ & - & - \\
\hline Poliklinik & 2.33 & 4.80 & - & $\mathrm{O}$ & - & - \\
\hline Dokter Jaga & 1.83 & 4.57 & - & $\mathrm{O}$ & - & - \\
\hline $\begin{array}{l}\text { Kerjasama dengan rumah } \\
\text { sakit yang dekat }\end{array}$ & 4.10 & 4.83 & $\mathrm{O}$ & - & - & - \\
\hline $\begin{array}{l}\text { Informasi yang } \\
\text { dipublikasi }\end{array}$ & 2.47 & 4.60 & - & $\mathrm{O}$ & - & - \\
\hline $\begin{array}{l}\text { Keterawatan } \\
\text { infrastructure }\end{array}$ & 3.17 & 4.83 & $\mathrm{O}$ & - & - & - \\
\hline $\begin{array}{l}\text { Ketersediaan dan } \\
\text { keandalan Wifi }\end{array}$ & 1.37 & 2.50 & - & - & $\mathrm{O}$ & - \\
\hline Toilet & 2.27 & 4.63 & - & $\mathrm{O}$ & - & - \\
\hline Fasilitas umum & 3.23 & 4.23 & - & - & - & $\mathrm{O}$ \\
\hline Signage & 3.93 & 4.77 & $\mathrm{O}$ & - & - & - \\
\hline Papan Informasi & 3.60 & 4.53 & $\mathrm{O}$ & - & - & - \\
\hline
\end{tabular}




\begin{tabular}{|c|c|c|c|c|c|c|}
\hline Risk Operasional Event & $\begin{array}{l}\text { Rata-Rata } \\
\text { Performance }\end{array}$ & $\begin{array}{l}\text { Rata-Rata } \\
\text { Importance }\end{array}$ & $\begin{array}{l}\text { Zona } \\
1\end{array}$ & $\begin{array}{l}\text { Zona } \\
2\end{array}$ & $\begin{array}{l}\text { Zona } \\
3\end{array}$ & $\begin{array}{l}\text { Zona } \\
4\end{array}$ \\
\hline Jogging Track & 2.40 & 3.00 & - & - & $\mathrm{O}$ & - \\
\hline Jalan & 3.73 & 4.73 & $\mathrm{O}$ & - & - & - \\
\hline Tempat Parkir & 2.87 & 4.83 & - & $\mathrm{O}$ & - & - \\
\hline Aksesibilitas & 3.73 & 4.67 & $\mathrm{O}$ & - & - & - \\
\hline $\begin{array}{l}\text { Fasilitas dapat diakses } \\
\text { via online }\end{array}$ & 2.43 & 3.33 & - & - & $\mathrm{O}$ & - \\
\hline Ruangan ber AC & 1.23 & 1.30 & - & - & $\mathrm{O}$ & - \\
\hline $\begin{array}{l}\text { Lingkungan yang } \\
\text { rindang }\end{array}$ & 4.57 & 4.77 & $\mathrm{O}$ & - & - & - \\
\hline Pepohonan rindang & 4.70 & 4.83 & $\mathrm{O}$ & - & - & - \\
\hline Penataan Infrastruktur & 4.10 & 4.83 & $\mathrm{O}$ & - & - & - \\
\hline Penataan Lingkungan & 3.50 & 4.87 & $\mathrm{O}$ & - & - & - \\
\hline $\begin{array}{l}\text { Antrian masuk dan } \\
\text { keluar destinasi wisata }\end{array}$ & 3.80 & 4.70 & $\mathrm{O}$ & - & - & - \\
\hline $\begin{array}{l}\text { Penempatan pedagang } \\
\text { kaki lima }\end{array}$ & 3.17 & 4.73 & $\mathrm{O}$ & - & - & - \\
\hline Pelayanan yang sigap & 2.93 & 4.63 & - & $\mathrm{O}$ & - & - \\
\hline $\begin{array}{l}\text { Pelayanan yang } \\
\text { membantu }\end{array}$ & 2.63 & 4.50 & - & $\mathrm{O}$ & - & - \\
\hline Kotak saran & 2.00 & 4.47 & - & $\mathrm{O}$ & - & - \\
\hline Inovasi Pengelola & 2.23 & 4.67 & - & $\mathrm{O}$ & - & - \\
\hline Fasilitas umum & 3.23 & 4.40 & - & - & - & $\mathrm{O}$ \\
\hline $\begin{array}{l}\text { Kepekaan petugas } \\
\text { terhadap kesulitan } \\
\text { pengunjung }\end{array}$ & 2.50 & 4.37 & - & - & $\mathrm{O}$ & - \\
\hline Informasi promosi & 2.50 & 4.17 & - & - & $\mathrm{O}$ & - \\
\hline Tenaga kerja & 2.50 & 4.60 & - & $\mathrm{O}$ & - & - \\
\hline Rata-Rata & 2.946 & 4.401 & & & & \\
\hline
\end{tabular}

Dari hasil sebaran kuisioner yang disebar oleh tim survey di lokasi Taman Cibodas, dari aspek penting dan performa dari Sapta Pesona, peneliti rangkum dalam temuan berikut ini:

Pada Zona 1 tabel 2. aspek mencakup Pos Informasi, Keamanan, Ketersediaan Rumah Sakit, Infrastruktur secara umum yang di dalamnya termasuk signage, papan informasi, jalan dan aksesibilitas sudah dalam kondisi sangat baik dan dinilai oleh para pengunjung juga merupakan aspek yang sangat penting dalam pengelolaan Taman Wisata. Selain itu lingkungan secara general luas dan sejuk, karena hawa pegunungan dan terdapat beberapa pepohonan yang tinggi. Antrian masuk dan keluar yang sangat baik, serta penempatan pedangang kaki lima juga sudah sangat baik. Sekalipun penempatan pedagang kaki lima sangat baik akan tetapi dari sisi manajemen, penetapan harga masih sangat 
kurang. Pada bagian sebelumnya peneliti menyarankan untuk membentuk sebuah koperasi desa untuk membantu manajemen usaha bagi pedagang kaki lima ini. Zona 1 ini adalah zona tingkat kepentingan tinggi dan juga tingkat performa yang sangat baik. Aspek yang telah disebutkan di atas bagi pengelola Taman Cibodas harus tetap diperhatikan keberlanjutannya. Tentunya peneliti juga menggarisbawahi pentingnya ada koperasi untuk menjadi wadah bagi para pedagang kaki lima yang telah diberikan tempat di dalam Taman Cibodas ini.

Berikut ini adalah beberapa catatan penting yang harus ditingkatkan oleh pengelola Taman Cibodas. Aspek berikut ini adalah aspek manajemen risiko yang berada di Zona 2, yang secara performa masih dirasa kurang oleh pengunjung dan aspek ini juga sebenarnya dianggap penting oleh pengunjung. Aspek-aspek yang masuk dalam Zona 2 adalah sebagai berikut:

Tabel 3. Indikator Risiko Operasional yang Perlu Ditingkatkan pada Taman Nasional Cibodas (Zona 2)

\begin{tabular}{ll}
\hline No & Risiko Operasional \\
\hline 3 & Ketersediaan Informasi \\
5 & Kualitas tenaga kerja \\
6 & Kecukupan jumlah petugas \\
7 & Poliklinik \\
8 & Dokter Jaga \\
10 & Informasi yang dipublikasi \\
13 & Toilet \\
19 & Tempat Parkir \\
29 & Pelayanan yang sigap \\
30 & Pelayanan yang membantu \\
31 & Kotak saran \\
32 & Inovasi Pengelola \\
36 & Tenaga kerja \\
\hline
\end{tabular}

Berikut ini adalah penjelasan dari temuan indikator di atas:

\section{Ketersediaan Informasi.}

Informasi yang dimaksud adalah peta Taman Cibodas, informasi tourist spot yang menarik, serta selebaran-selebaran yang memberikan informasi tambahan mengenai Taman Cibodas. Tim survey dan peneliti tidak menemukan ketersediaan selebaran atau flyer yang dimaksud. Jika memang ingin membuat Taman Wisata dengan level Internasional harusnya pengelola juga mulai berpikir untuk mulai membuat flyer ini sebagai peta kecil turis 
selama berkunjung di Taman Cibodas. Manfaatnya yaitu para pengunjung dan turis akan merasa nyaman dan dengan baik dapat merencanakan spot-spot di mana saja yang bagi mereka menarik untuk dikunjungi.

\section{Kualitas Tenaga Kerja}

Tim survey dan peneliti juga tidak menemukan adanya petugas yang standby di pos untuk ditanyai seputar Taman Cibodas ini. Tim Survey juga telah mencoba untuk bertanya kepada masyarakat di daerah tersebut dan masih kurangnya product knowledge dari masyarakat sendiri yang menurut peneliti menjadi hambatan pengembangan potensi wisata Taman Cibodas ini. Ada baiknya ada duta Taman Cibodas yang secara berkala diberikan pelatihan mengenai hospitality dan product knowledge sehingga dapat meningkatkan kenyamanan para pengunjung.

\section{Kecukupan Petugas}

Masih sejalan dengan temuan pada pengamatan, kecukupan petugas masih dirasa kurang. Pengelola perlu menambah lebih banyak petugas, terutama pada bagian informasi dan beberapa spot turis. Diharapkan dengan penambahan petugas, maka akses informasi ke pengunjung akan lebih baik sehingga pesona Taman
Cibodas tersampaikan dengan baik ke hati pengunjung.

\section{Poliklinik \& Dokter Jaga}

Memang Taman Cibodas dekat dengan Rumah Sakit Cimacan, akan tetapi di dalam komplek Taman Cibodas yang sangat luas sendiri, tim survey dan peneliti tidak menemukan adanya poliklinik dan dokter jaga yang memadai. Berdasarkan hasil pantauan tim survey, jika ada pengunjung yang sakit, maka pertolongan pertama diberikan di pos pengamanan saja. Oleh karena itu pihak pengelola juga perlu memastikan tersedianya fasilitas poliklinik dan dokter jaga jika memang terjadi hal yang tidak diinginkan sehingga para pengunjung dapat ditangani dengan baik sebelum dibawa ke Rumah Sakit.

\section{Toilet}

Fasilitas toilet menjadi fasilitas penunjang yang sangat penting dalam tempat wisata. Akan tetapi jika memang sudah ada, maka penting sekali bagi pengelola untuk memastikan kebersihan toilet tersebut. Temuan dari tim survey dan peneliti baik dari pengamatan ataupun dari hasil kuisioner yang dibagikan, kondisi toilet di tempat wisata masih kurang terawat dengan baik dan juga masih kurang bersih. Pihak pengelola harus menjaga kebersihan toilet dengan baik, dengan tujuan dapat 
meningkatkan kenyamanan bagi pengunjung.

\section{Lahan Parkir}

Untuk fasilitas lahan parkir, tim survey dan peneliti, memang menemukan lahan parkir tersedia dengan baik. Akan tetapi dari pengamatan dan juga hasil kuisioner, pengunjung menghendaki lahan parkir yang lebih luas dan tidak terlalu jauh dari wahana atau tourist spot dari Taman Cibodas. Hal ini dirasa bisa meningkatkan aksesabilitas dari para pengunjung Taman Cibodas.

\section{Pelayanan oleh petugas yang sigap dan membantu}

Selain terkendala oleh product knowledge yang baik, petugas disini juga masih kurang dari sisi kesigapan dalam menolong pengunjung. Tim survey merasa masih kurangnya inisiatif petugas dalam menolong pengunjung. Solusi atas point ini adalah pengelola harus memberikan pelatihan hospitality untuk meningkatkan baik soft skill maupun product knowledge dari setiap petugas Taman Cibodas.

\section{Innovasi pengelola}

Tim survey dan peneliti merasa kurangnya innovasi yang dibuat pengelola untuk membuat tourist attraction di Taman Cibodas ini. Padahal jika memang bisa dikemas dengan baik, maka tim pengelola dapat mengemas beberapa event ataupun pengenalan budaya local kepada para pengunjung. Selain itu jika memang berhasil dengan event dan pengenalan budaya local, penduduk setempat dapat meningkatkan kesejahteraan dengan berjualan barang-barang buah tangan bernuansa local. Selain itu kurangnya nilai estetika dari bangunan dan layout Taman Cibodas juga harus diperbaiki oleh pengelola. Desain cenderung monoton dan membosankan. Pengelola dapat mempertimbangkan mulai membuat studi kelayakan untuk membuat beberapa tourist attraction yang mungkin memiliki potensi untuk menarik orang-orang berlibur ke Taman Cibodas. Hasil yang diharapkan dari innovasi ini adalah Taman Cibodas masih tetap sustainable.

\section{Sumber daya Manusia}

Selanjutnya adalah jika strategic planning yang mencakup innovasi dan juga sasaran pengunjung sudah dibuat dengan baik, tidak lupa peneliti juga merasa penting sekali dalam pengembangan Sumber Daya Manusia. Selain memberikan saran untuk pengembangan skill hospitality maka tidak lupa para petugas disini dapat dikembangkan skill yang lain secara baik terutama dalam bidang pemanfaatan teknologi dan juga manajerial. Hal ini peneliti rasa bisa mulai dilaksanakan dengan mulai dibuatnya koperasi kecil 
untuk para pedagang kaki lima dan mulai diatur secara baik keuangan dan administrasinya. Tujuannya adalah selain dapat meningkatkan tourist satisfaction maka hal ini juga dapat meningkatkan ekonomi serta kesejahteraan masyarakat sekitar Taman Cibodas.

Pada zona 3, peneliti menemukan aspekaspek seperti Ketersediaan wifi, Jogging Track, Akses Online, Ruang ber AC, Informasi Promosi, Pengetahuan petugas akan lokasi wisata dan juga kepekaan petugas dalam melakukan inisiatif membantu pengunjung secara performa masih kurang (di bawah rata-rata). Akan tetapi memang berdasarkan hasil survey bagi pengunjung aspek ini masih dirasa kurang penting pada Taman Cibodas. Tentunya sebagai contoh, fasilitas Ruangan ber AC, Jogging Track, Akses Online bukan menjadi selling point dari
Taman Cibodas ini. Saran peneliti adalah akan lebih baik jika beberapa penganggaran menyangkut aspek pada zona 3 ini dialokasikan terlebih dahulu ke perbaikan zona 2. Sehingga penggunaan anggaran menjadi tepat guna.

Evaluasi terakhir pada aspek ini adalah Zona 4. Zona 4 adalah zona di mana aspek ini telah dikelola sangat baik oleh pengelola akan tetapi bagi pengunjung aspek ini kurang terlalu penting untuk diperhatikan. Atau dengan kata lain aspek pada zona 4 ini (aspek fasilitas umum) adalah aspek yang overperform. Dari sisi tersedianya fasilitas umum sudah sangat baik, jadi selanjutnya pengelola dapat focus kepada innovasi dan desain dari fasilitas umum ini yang lebih baik dan estetik untuk meningkatkan minat pengunjung Taman Cibodas.

\section{Performance - Importance Kuadrat (Cibeureum)}

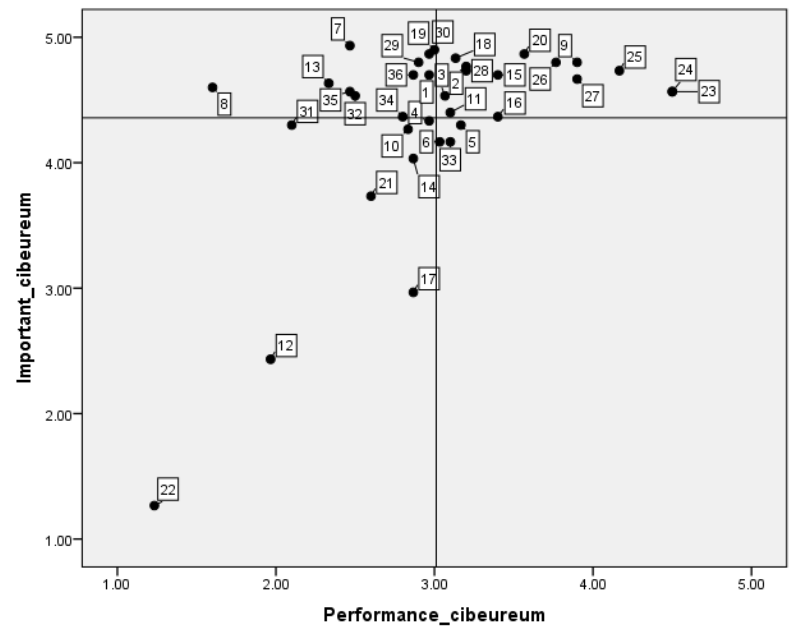

Gambar 5. Kuadran Risiko Untuk Taman Nasional Gunung Gede-Pangrango (Tourist SpotAir Terjun Cibeureum) 
Tabel 4. Indikator Risiko Air Terjun Cibeureum

\begin{tabular}{|c|c|c|c|c|c|c|}
\hline $\begin{array}{l}\text { Risk Operasional } \\
\text { Event }\end{array}$ & $\begin{array}{l}\text { Rata-Rata } \\
\text { Performance }\end{array}$ & $\begin{array}{l}\text { Rata-Rata } \\
\text { Importance }\end{array}$ & Zona 1 & Zona 2 & Zona 3 & Zona 4 \\
\hline Pos Informasi & 2.9667 & 4.7000 & - & $\mathrm{O}$ & - & - \\
\hline $\begin{array}{l}\text { Keamanan } \\
\text { Lingkungan wisata }\end{array}$ & 3.2000 & 4.7667 & $\mathrm{O}$ & - & - & - \\
\hline $\begin{array}{l}\text { Ketersediaan } \\
\text { Informasi }\end{array}$ & 3.0667 & 4.5333 & $\mathrm{O}$ & - & - & - \\
\hline $\begin{array}{l}\text { Pengetahuan Petugas } \\
\text { akan Lokasi Wisata }\end{array}$ & 2.9667 & 4.3333 & - & - & $\mathrm{O}$ & - \\
\hline Kualitas tenaga kerja & 3.1667 & 4.3000 & - & - & - & $\mathrm{O}$ \\
\hline $\begin{array}{l}\text { Kecukupan jumlah } \\
\text { petugas }\end{array}$ & 3.0333 & 4.1667 & - & - & - & $\mathrm{O}$ \\
\hline Poliklinik & 2.4667 & 4.9333 & - & $\mathrm{O}$ & - & - \\
\hline Dokter Jaga & 1.6000 & 4.6000 & - & $\mathrm{O}$ & - & - \\
\hline $\begin{array}{l}\text { Kerjasama dengan } \\
\text { rumah sakit yang } \\
\text { dekat }\end{array}$ & 3.9000 & 4.8000 & $\mathrm{O}$ & - & - & - \\
\hline $\begin{array}{l}\text { Informasi yang } \\
\text { dipublikasi }\end{array}$ & 2.8333 & 4.2667 & - & - & $\mathrm{O}$ & - \\
\hline $\begin{array}{l}\text { Keterawatan } \\
\text { infrastructure }\end{array}$ & 3.1000 & 4.4000 & $\mathrm{O}$ & - & - & - \\
\hline $\begin{array}{l}\text { Ketersediaan dan } \\
\text { keandalan Wifi }\end{array}$ & 1.9667 & 2.4333 & - & - & $\mathrm{O}$ & - \\
\hline Toilet & 2.3333 & 4.6333 & - & $\mathrm{O}$ & - & - \\
\hline Fasilitas umum & 2.8667 & 4.0333 & - & - & $\mathrm{O}$ & - \\
\hline Signage & 3.4000 & 4.7000 & $\mathrm{O}$ & - & - & - \\
\hline Papan Informasi & 3.4000 & 4.3667 & $\mathrm{O}$ & - & - & - \\
\hline Jogging Track & 2.8667 & 2.9667 & - & - & $\mathrm{O}$ & - \\
\hline Jalan & 3.1333 & 4.8333 & $\mathrm{O}$ & - & - & - \\
\hline Tempat Parkir & 3.0000 & 4.9000 & - & $\mathrm{O}$ & - & - \\
\hline Aksesibilitas & 3.5667 & 4.8667 & $\mathrm{O}$ & - & - & - \\
\hline $\begin{array}{l}\text { Fasilitas dapat diakses } \\
\text { via online }\end{array}$ & 2.6000 & 3.7333 & - & - & $\mathrm{O}$ & - \\
\hline Ruangan ber AC & 1.2333 & 1.2667 & - & - & $\mathrm{O}$ & - \\
\hline $\begin{array}{l}\text { Lingkungan yang } \\
\text { rindang }\end{array}$ & 4.5000 & 4.5667 & $\mathrm{O}$ & - & - & - \\
\hline Pepohonan rindang & 4.5000 & 4.5667 & $\mathrm{O}$ & - & - & - \\
\hline Penataan Infrastruktur & 4.1667 & 4.7333 & $\mathrm{O}$ & - & - & - \\
\hline Penataan Lingkungan & 3.7667 & 4.8000 & $\mathrm{O}$ & - & - & - \\
\hline $\begin{array}{l}\text { Antrian masuk dan } \\
\text { keluar destinasi wisata }\end{array}$ & 3.9000 & 4.6667 & $\mathrm{O}$ & - & - & - \\
\hline $\begin{array}{l}\text { Penempatan pedagang } \\
\text { kaki lima }\end{array}$ & 3.2000 & 4.7333 & $\mathrm{O}$ & - & - & - \\
\hline Pelayanan yang sigap & 2.9000 & 4.8000 & - & $\mathrm{O}$ & - & - \\
\hline $\begin{array}{l}\text { Pelayanan yang } \\
\text { membantu }\end{array}$ & 2.9667 & 4.8667 & - & $\mathrm{O}$ & - & - \\
\hline Kotak saran & 2.1000 & 4.3000 & - & - & $\mathrm{O}$ & - \\
\hline
\end{tabular}




\begin{tabular}{lcccccc}
\hline $\begin{array}{l}\text { Risk Operasional } \\
\text { Event }\end{array}$ & $\begin{array}{l}\text { Rata-Rata } \\
\text { Performance }\end{array}$ & $\begin{array}{l}\text { Rata-Rata } \\
\text { Importance }\end{array}$ & Zona 1 & Zona 2 & Zona 3 & Zona 4 \\
\hline Inovasi Pengelola & 2.5000 & 4.5333 & - & $\mathrm{O}$ & - & - \\
$\begin{array}{l}\text { Fasilitas umum } \\
\text { Kepekaan petugas } \\
\text { terhadap kesulitan }\end{array}$ & 3.1000 & 4.1667 & - & - & - & $\mathrm{O}$ \\
$\begin{array}{l}\text { pengunjung } \\
\text { Informasi promosi }\end{array}$ & 2.8000 & 4.3667 & - & $\mathrm{O}$ & - & - \\
Tenaga kerja & 2.4667 & 4.5667 & - & $\mathrm{O}$ & - & - \\
\hline
\end{tabular}

Tim survey dan peneliti, melakukan beberapa observasi juga pada kawasan Taman Nasional Gunung Gede Pangrango. Dalam melakukan observasi tim survey dan peneliti juga ikut melakukan pendakian ringan dari pintu masuk Gunung Gede Pangarango hingga Air Terjun Cibeureum.

Kondisi toilet yang teramati masih kurang baik. Selain itu jarak dari tourist spot ke tourist spot yang lain tidak diakomodir jumlah toilet yang memadai. Berdasarkan hasil pengamatan kurang lebih jarak toilet adalah $600 \mathrm{~m}$. Sisi positif dari toilet di kawasan ini adalah ketersediaan air melimpah dan tidak bau. Akan tetapi karena memang di dalam hutan, kondisi toilet sedikit berlumut. Untuk penjual makanan di sini, masih mirip dengan penjual makanan di Taman Cibodas. Penetapan harga masih tidak memiliki standarisasi yang baik. Jalan menuju air terjun Cibeureum cukup jauh akan tetapi masih landau. Merupakan pendakian ringan bagi pendaki pemula. Hanya saja terdapat jembatan yang dalam kondisi tidak baik. Ada baik pihak pengelola segera melakukan perbaikan supaya pengunjung tidak terjatuh atau mengalami kecelakaan sewaktu mendaki. Pos penjagaan juga tidak ada, sehingga untuk masalah keselamatan dan keamanan pengunjung tim survey merasa masih perlu ditingkatkan. Tenaga medis juga tidak ada dan selain itu pihak pengelola dan "Ranger" hanya mengandalkan tenaga relawan saja. Identifikasinya hanya pada penggunaan name tag saja. Untuk papan penunjuk arah sudah cukup baik, akan tetapi pada persimpangan Panyancangan, perlu adanya tambahan INFORMASI mengenai kondisi apa saja yang memungkinkan orang untuk mendaki ke arah Gunung Gede dan Pangrango. Berdasarkan aturan pengelola, hanya pendaki yang memiliki izin dari tim di pos paling bawah diperbolehkan mendaki ke arah yang lebih tinggi. Oleh sebab itu tim survey merasa penting sekali untuk ada tambahan papan informasi untuk 
peringatan tersebut. Dari segi pengelola juga sudah menerapkan sistem dan pencatatan sederhana untuk membatasi jumlah pendaki. Tim survey merasa temuan ini sangat baik terutama untuk tujuan kenyamanan dan keselamatan pengunjung. Selain itu dari temuan tim survey ada asuransi yang dicover untuk pengunjung hingga air terjun Cibeureum. Menurut tim survey ini sudah merupakan langkah yang sangat baik untuk memberikan rasa aman dan proteksi kepada pengunjung. Tulisan asuransi ini ditemukan pada tiket masuk. Jalan menunju air terjun Cibeureum cukup berbatu besar, hanya saja landau. Pengunjung tetap harus menjaga keseimbangan dan memperhatikan kaki supaya tidak terkilir. Sampai air terjun Cibeureum masih direkomendasi untuk hampir semua umur pendaki akan tetapi untuk pendaki yang mengalami cidera lutut tetap harus memperhatikan kondisi kaki terlebih dahulu sebelum melakukan pendakian. Ditemukan beberapa petunjuk jarak dan ketinggian di lokasi pendakian. Cukup informatif untuk membantu para pendaki, akan tetapi ada beberapa lokasi petunjuk jarak tidak ditemukan ataupun tidak kelihatan. Ada baiknya pihak pengelola mengecek petunjuk jarak tersebut dengan tujuan hal ini sangat memudahkan pendaki untuk mengetahui estimasi waktu pendakian mereka hingga sampai di tempat yang dituju.

Selain mengandalkan observasi, tim survey juga melakukan pembagian kuisoner sederhana ke beberapa pengunjung yang bersedia di lokasi pendakian. Berdasarkan hasil kuisioner tersebut, tim survey juga membuat kuadran risiko pada gambar 5, sekaligus merangkum beberapa hal penting yang perlu diperhatikan oleh manajemen atau pengelola Taman Nasional Gunung Gede Pangrango, kawasan Air Terjun Cibeureum terkait dengan manajemen risiko operasional tempat wisata tersebut. Indikator risiko seperti keamanan lingkungan wisata, ketersediaan informasi, kerjasama dengan rumah sakit terdekat, infrasturktur, papan penunjuk jalan dan informasi, aksesibilitas, jalan, kondisi lingkungan dan penataannya serta antrian masuk dan keluar dan penempatan pedagang kaki lima, secara keseluruhan memiliki nilai performa yang baik bagi para pengunjung / pendaki. Pendaki sudah cukup ok dengan ketersediaan pos jaga pada pintu masuk dan beberapa prosedur pengecekan sebelum melakukan pendakian, hal ini dirasa sangat bagus untuk menjamin keamanan pendakian. Ketersediaan informasi juga sudah dirasa cukup ok karena papan penunjuk jalan sudah baik dan mampu menghindarkan pendaki dari salah arah. Lingkungan, 
infrastruktur dan jalan pendakian juga sudah baik, hanya saja catatan bagi pengelola pada beberapa spot jembatan yang berlubang ada baiknya segera diperbaiki. Aspek-aspek ini masuk dalam Zona 1 kuadran risiko, yang merupakan aspek dengan performa yang baik serta tingkat kepentingan yang tinggi.
Berikut ini adalah indikator risiko yang berada pada Zona 2 . Indikator risiko yang berada pada zona 2 ini adalah risiko yang bagi pengunjung / pendaki merupakan indikator yang cukup penting akan tetapi dirasa masih kurang memuaskan atau kurang baik performanya.

Tabel 5. Indikator Risiko Operasional yang Perlu Ditingkatkan pada Kawasan Wisata Air Terjun Cibeureum (Zona 2)

\begin{tabular}{ll}
\hline No & Risk Operasional Event \\
\hline 1 & Pos Informasi \\
7 & Poliklinik \\
8 & Dokter Jaga \\
13 & Toilet \\
19 & Tempat Parkir \\
29 & Pelayanan yang sigap \\
30 & Pelayanan yang membantu \\
32 & Inovasi Pengelola \\
34 & Kepekaan petugas terhadap kesulitan pengunjung \\
35 & Informasi promosi \\
36 & Tenaga kerja \\
\hline
\end{tabular}

Berikut ini adalah penjelasan dari temuan indikator di atas:

\section{Pos Informasi}

Pos informasi memang tersedia pada pos pertama pendakian. Akan tetapi begitu sudah mendaki sudah tidak ada lagi pos informasi yang mendukung atau menjadi tempat para pendaki untuk mencari informasi lebih lanjut mengenai tourist spot tersebut. Menurut peneliti, ada baiknya pengelola juga menambahkan pos informasi di air terjun Cibeureum sebab dari sasaran pengunjung, lokasi ini adalah yang masih mungkin menarik minat dan mampu didaki oleh semua umur. Dengan adanya pos informasi tersebut diharapkan kenyamanan dan keamanan pengunjung dapat meningkat.

\section{Poliklinik dan Dokter Jaga}

Mirip dengan Taman Cibodas, kurang adanya Poliklinik dan dokter jaga yang memadai di lokasi pendakian. Memang cukup sulit untuk membuat poliklinik di setiap tourist spot akan tetapi saran dari peneliti adalah pengelola sudah harus 
memberdayakan pos masuk pertama sebagai poliklinik kecil dan tempat siaga dokter jaga. Dengan adanya poliklinik yang memadai maka diharapkan pengecekan awal dapat dengan akurat memberikan informasi kesehatan pendaki, dengan tujuan pengelola juga menghindari kecelakaan ataupun hal yang tidak diinginkan terjadi pada pendaki yang tidak sehat.

\section{Toilet dan Tempat Parkir}

Untuk toilet memang berdasarkan observasi dan pendapat beberapa pengunjung, kondisi sebenarnya sudah baik, akan tetapi dari segi tampilan, ada baiknya pengelola juga secara berkala membersihkan lumut-lumut yang ada pada toilet, terutama toilet pada lokasi yang sudah tinggi. Dengan menjamin tampilan yang bersih maka pendaki atau pengunjung juga dapat lebih nyaman untuk buang air kecil. Kondisi tempat parkir cukup jauh dari pos pertama lokasi pendakian. Ada baiknya khusus untuk para pendaki Gunung Gede dapat parkir lebih dekat lagi ke lokasi pendakian.

\section{Pelayanan yang sigap dan membantu}

Dari sisi petugas, karena temuan tim survey dan peneliti adalah pada umumnya petugas disini adalah sifatnya volountery (relawan) maka kesigapan dalam membantu juga masih kurang. Pengelola juga harus meningkatkan kapabilitas dengan mulai menambah wawasan mengenai pariwisata terutama untuk masalah hospitality. Sehingga hal ini dapat menambah nilai jual lokasi Taman Nasional Gunung Gede Pangrango

\section{Innovasi pengelola}

Pihak pengelola juga perlu meningkatkan innovasi untuk menarik minat orang yang datang ke Taman Nasional ini menjadi lebih banyak. Berdasarkan hasil tanya jawab dengan beberapa pengelola, mereka memang sudah mulai berinnovasi untuk membuatkan program Naik Gunung Cantik, bagi beberapa pendaki yang tidak berpengalaman atau yang masih baru pertama mendaki gunung. Tanpa harus repot mempersiapkan semua perlengkapan, pengunjung cukup datang membawa beberapa kebutuhan pribadi saja dan semua tenda sudah disiapkan di atas. Para pendaki pemula juga diberikan pendampingan selama mendaki oleh tim pengelola untuk memastikan pendaki sampai dengan selamat baik naik dan turun dari gunung. Menurut tim peneliti ini adalah innovasi yang cukup baik, akan tetapi memang masih kurang sounding dan terdengar bagi banyak orang. Ada baiknya adanya papan informasi khusus untuk ini atau dibuatkannya campaign khusus untuk meningkatkan kecintaan orang-orang akan kegiatan mendaki gunung tersebut. 


\section{Kepekaan Petugas}

Masih terkait dengan kesigapan petugas, hal ini juga dikarenakan sifat penugasan adalah volountary (relawan). Untuk meningkatkan hal ini pengelola harus bisa memfasilitasi tim relawan dengan pembinaan hospitality sehingga para relawan juga dari sisi edukasi dapat menjadi lebih baik dan menjadi duta Gunung Gede Pangarango.

\section{Informasi Promosi}

Materi promosi sangat kurang. Terutama untuk campaign pengelola untuk meningkatkan jumlah pengunjung dengan adanya naik gunung cantik tersebut tidak begitu terdengar. Penting sekali pengelola punya tim kreatif untuk membuat materi promosi untuk setiap kegiatan di Taman Nasional Gunung Gede Pangrango ini sehingga dapat menarik minat orang. Promosi bisa dilakukan secara online yakni pemanfaatan social media. Oleh karena itu tim peneliti menyarankan pengelola juga meningkatkan kapabilitas dari sisi teknologi, terutama pemanfaatannya dalam kegiatan promosi.

\section{Sumber Daya Manusia}

Pengelola cukup memiliki pekerjaan rumah yang banyak menurut peneliti. Pengembangan Sumber Daya Manusia untuk tim relawan dan manajerial untuk pengelolaan Taman Nasional Gunung Gede ini sangat penting. Pembentukan koperasi untuk menunjang kegiatan pembiayaan dan manajerial bisa menjadi jembatan pertama bagi pengelola untuk bekerja lebih professional. Selain itu tim pengelola juga harus mengembangkan kapabilitas di bidang kreativitas, pemanfaatan social media, serta kemampuan di bidang hospitality yang lebih baik. Sasarannya adalah tim dapat memberikan experience terbaik bagi para pengunjung sehingga lokasi ini dapat menjadi sumber kekayaan local yang berguna bagi ekonomi masyarakat sekitar.

Dari indikator, pengetahuan petugas akan lokasi wisata, informasi yang dipublikasi, ketersediaan wifi, fasilitas umum, jogging track, akses informasi fasilitas secara online, ruangan ber AC dan kotak saran, adalah indikator pada Zona 3. Beberapa indikator disini bagi peneliti mungkin harus dikaji lagi apakah sesuai dengan kondisi Kawasan Wisata ini. Peneliti juga merasa kurang cukup ok untuk mengukur fasilitas AC dan Keandalan Wifi dalam kasus ini. Akan tetapi dari peta risiko, indikator ini memang secara performa kurang dan juga kurang penting. Sehingga dalam pengembangannya menjadi prioritas terakhir saja.

Pada Zona 4, hanya terdapat indikator, yakni kualitas tenaga kerja, kecukupan jumlah petugas dan fasilitas umum. Bagi 
sebagian besar pengunjung performa indikator ini sudah baik, hanya dirasa masih kurang penting saja. Akan tetapi bagi peneliti indikator ini tetap harus dipertahankan performanya dalam rangka meningkatkan kenyamanan pengunjung. Dalam sisi pengembangan Zona 4 ini memang perlu sedikit dialokasikan sumber dayanya untuk pengembangan Zona 2 terlebih dahulu. Sisi fasilitas yang telah baik infrastrukturnya tercermin dari hiking trail yang telah sengaja dibuat untuk memudahkan pendaki supaya tidak tersasar.

\section{Uji Validitas dan Reliabilitas}

Tabel 6. Hasil Uji Validitas Kuisioner Taman Nasional Gunung Gede Pangrango - Air

Terjun Cibeureum

\begin{tabular}{|c|c|c|c|c|}
\hline Validity Test & Performance & sig & Importance & sig \\
\hline R1 & 0.808 & $*$ & 0.751 & $*$ \\
\hline $\mathrm{R} 2$ & 0.883 & $*$ & 0.734 & $*$ \\
\hline R3 & 0.707 & $*$ & 0.779 & $*$ \\
\hline $\mathrm{R} 4$ & 0.705 & $*$ & 0.65 & $*$ \\
\hline R5 & 0.877 & $*$ & 0.732 & $*$ \\
\hline R6 & 0.802 & $*$ & 0.761 & $*$ \\
\hline A1 & 0.871 & $*$ & 0.761 & $*$ \\
\hline $\mathrm{A} 2$ & 0.741 & $*$ & 0.896 & $*$ \\
\hline A3 & 0.874 & $*$ & 0.82 & $*$ \\
\hline A4 & 0.669 & $*$ & 0.753 & $*$ \\
\hline $\mathrm{T} 1$ & 0.341 & & 0.677 & $*$ \\
\hline $\mathrm{T} 2$ & 0.376 & $*$ & 0.203 & \\
\hline $\mathrm{T} 3$ & -0.378 & $*$ & -0.218 & \\
\hline $\mathrm{T} 4$ & 0.279 & & -0.014 & \\
\hline T5 & 0.371 & $*$ & -0.183 & \\
\hline T6 & -0.023 & & -0.011 & \\
\hline $\mathrm{T} 7$ & 0.742 & $*$ & -0.311 & \\
\hline $\mathrm{T} 8$ & 0.61 & $*$ & -0.032 & \\
\hline T9 & 0.216 & & -0.178 & \\
\hline $\mathrm{T} 10$ & 0.638 & $*$ & -0.122 & \\
\hline T11 & 0.641 & $*$ & 0.01 & \\
\hline $\mathrm{T} 12$ & 0.164 & & 0.097 & \\
\hline $\mathrm{T} 13$ & 0.151 & & 0.204 & \\
\hline $\mathrm{T} 14$ & -0.187 & & 0.168 & \\
\hline $\mathrm{T} 15$ & 0.661 & $*$ & 0.377 & $*$ \\
\hline T16 & 0.044 & & -0.165 & \\
\hline E1 & -0.104 & & 0.042 & \\
\hline E2 & -0.274 & & 0.676 & $*$ \\
\hline E3 & 0.879 & $*$ & 0.538 & $*$ \\
\hline E4 & 0.629 & $*$ & 0.552 & $*$ \\
\hline E5 & 0.454 & $*$ & 0.757 & $*$ \\
\hline
\end{tabular}




\begin{tabular}{lllll}
\hline Validity Test & Performance & sig & Importance & sig \\
\hline E6 & 0.646 & $*$ & 0.593 & $*$ \\
E7 & 0.568 & $*$ & 0.597 & $*$ \\
E8 & 0.583 & $*$ & 0.497 & $*$ \\
Res1 & 0.76 & $*$ & 0.895 & $*$ \\
Res2 & 0.806 & $*$ & 0.824 & $*$ \\
\hline
\end{tabular}

Tabel 7. Hasil Uji Validitas Kuisioner Taman Cibodas

\begin{tabular}{lllll}
\hline Validity Test & Performance & sig & Importance & sig \\
\hline R1 & 0.503 & $*$ & 0.831 & $*$ \\
R2 & 0.753 & $*$ & 0.233 & \\
R3 & 0.764 & $*$ & 0.658 & $*$ \\
R4 & 0.759 & $*$ & 0.557 & $*$ \\
R5 & 0.73 & $*$ & 0.693 & $*$ \\
R6 & 0.577 & $*$ & 0.48 & $*$ \\
A1 & 0.814 & $*$ & 0.559 & $*$ \\
A2 & 0.697 & $*$ & 0.823 & $*$ \\
A3 & 0.855 & $*$ & 0.53 & $*$ \\
A4 & 0.739 & $*$ & 0.376 & $*$ \\
T1 & 0.47 & $*$ & 0.421 & $*$ \\
T2 & 0.427 & $*$ & 0.518 & $*$ \\
T3 & 0.081 & & 0.416 & $*$ \\
T4 & 0.331 & & 0.333 & \\
T5 & 0.38 & $*$ & 0.534 & $*$ \\
T6 & 0.511 & $*$ & 0.248 & \\
T7 & 0.508 & $*$ & 0.47 & $*$ \\
T8 & 0.428 & $*$ & 0.404 & $*$ \\
T9 & 0.392 & $*$ & 0.442 & $*$ \\
T10 & 0.514 & $*$ & 0.387 & $*$ \\
T11 & 0.593 & $*$ & 0.251 & \\
T12 & 0.299 & & 0.358 & \\
T13 & -0.042 & & 0.198 & \\
T14 & -0.178 & & 0.127 & \\
T15 & 0.612 & $*$ & 0.098 & \\
T16 & 0.334 & & 0.214 & \\
E1 & 0.283 & & 0.141 & \\
E2 & 0.28 & & 0.502 & $*$ \\
E3 & 0.636 & $*$ & 0.537 & $*$ \\
E4 & 0.517 & $*$ & 0.682 & $*$ \\
E5 & 0.388 & $*$ & 0.661 & $*$ \\
E6 & 0.608 & $*$ & 0.445 & $*$ \\
E7 & 0.634 & $*$ & 0.472 & $*$ \\
E8 & 0.714 & $*$ & 0.53 & $*$ \\
Res1 & 0.674 & $*$ & 0.722 & $*$ \\
Res2 & 0.816 & $*$ & 0.692 & $*$ \\
\hline & & & &
\end{tabular}


Tabel 8. Hasil Uji Reliabilitas Kuisioner Taman Nasional Gunung Gede Pangrango - Air Terjun Cibeureum

\begin{tabular}{lll}
\hline \multicolumn{1}{c}{$\begin{array}{c}\text { Reliability } \\
\text { Test }\end{array}$} & Performance & Importance \\
\hline Reliability & $0.8^{*}$ & $0.784^{*}$ \\
Assurance & $0.812^{*}$ & $0.814^{*}$ \\
Tangible & 0.625 & 0.613 \\
Empathy & 0.649 & $0.716^{*}$ \\
Responsivenes & $0.819^{*}$ & $0.829^{*}$ \\
\hline
\end{tabular}

Tabel 9. Hasil Uji Reliabilitas Kuisioner Taman Cibodas

\begin{tabular}{lll}
\hline \multicolumn{1}{c}{ Reliability } & Performance & Importance \\
\hline Reliability & $0.76^{*}$ & 0.625 \\
Assurance & $0.776^{*}$ & 0.315 \\
Tangible & 0.58 & 0.486 \\
Empathy & 0.627 & 0.57 \\
Responsivenes & 0.214 & 0 \\
\hline
\end{tabular}

Dari hasil uji validitas dan reliabilitas, terlihat pertanyaan pada kuisioner tersebut cukup baik dalam menggambarkan variabel penelitian. Nilai validitas yang pada kolom (sig) memiliki tanda $(*)$ artinya pertanyaan kuisioner valid dalam menggambarkan variabel penelitian. Sedangkan untuk reliabilitas, nilai yang lebih dari 0.7 maka pertanyaan kuisioner tersebut dinyatakan reliable dalam menggambarkan variabel penelitian. Dengan kata lain hampir sebagian besar pertanyaan dalam penelitian cukup representative dalam menggambarkan aspek manajemen risiko Gunung Gede Pangrango.

\section{Analisis SWOT}

Berdasarkan Analisis Risiko di atas maka Taman Nasional Gunung Gede Pangrango, baik Taman Cibodas dan Air terjun Cibeureum memiliki Kekuatan (Strength) sebagai berikut:

1. Secara infrastuktur dan fasilitas, sudah sangat baik. Ketersediaan berapa sarana dan prasarana di lokasi wisata seperti jalan, aksesabiltias, lingkungan alam sudah sangat nyaman untuk para pengunjung.

2. Potensi keindahan alam sekitar juga merupakan daya tarik bagi para turis dan pengunjung yang datang ke Taman Nasional Gunung Gede Pangrango. 
3. Selain itu lingkungan yang sejuk dan asri juga merupakan sebuah komoditi yang menjadi keunggulan tersendiri dari lokasi ini yang dijadikan tempat wisata oleh para pengunjung dari kota-kota besar seperti Jakarta dan Tangerang.

4. Untuk mendukung kenyamanan turis, Taman Nasional Gunung Gede Pangrango juga telah memberikan signage dan papan penunjuk arah yang jelas bagi pengunjung.

Taman Nasional Gunung Gede Pangrango sendiri memiliki kelemahan (Weakness) sebagai berikut:

1. Secara manajerial, Taman Nasional ini dari internal belum dilakukan secara professional dan baik. Hal ini nanti erat dengan beberapa aspek risiko operasional yang berhasil terukur oleh peneliti dari hasil observasi dan survey di lapangan.

2. Aspek pertama yang masih kurang dari sisi manajerial adalah pengembangan sumber daya manusia dari Taman Nasional itu sendiri. Belum adanya penerapan standard yang baik di lapangan, terutama untuk keaktifan, kepekaan dan keramahan dari petugas di lapangan. Bahkan masih banyak beberapa "calo" yang merupakan penduduk sekitar mengambil keuntungan tersendiri tanpa mengikuti manajemen Taman Nasional Gunung Gede Pangrango. Sebagai contoh tim suveryor menemukan beberapa anak kecil berusaha menjadi tourist guide tanpa adanya official uniform dan standard dari pengelola.

3. Karena kurangnya aspek manajerial dari pengembangan Sumber Daya Manusia maka tentunya beberapa aspek terkait perencanaan, pengembangan dan campaign terutama untuk informasi marketing masih sangat kurang dari Taman Nasional Gunung Gede Pangrango.

\section{Untuk sisi Kesempatan (Opportunity)} dari Taman Nasional Gunung Gede Pangarango adalah pasar untuk industry pariwisata ini sangat besar. Ditambah lagi kehidupan di perkotaan yang sudah sangat sibuk dan lingkungan perkotaan yang tidak asri menjadi komoditi yang ada pada Taman Nasional Gunung Gede Pangrango menjadi sebuah peluang bisnis yang sangat besar. Tidak perlu repot untuk mengukur potensi pasar, sebab hal itu peneliti dan tim survey temukan pada mobil dengan plat nomor B cukup banyak yang melintas ke arah Puncak dan menuju Taman Nasional Gunung Gede Pangrango. 
Sisi Ancaman (Thread) dari Taman Nasional Gunung Gede Pangrango aspek Innovasi menjadi sebuah perhatian khusus dari tim peneliti dan tim surveyor. Potensi pasar yang tinggi tadi akan sangat mudah gagal didapatkan oleh Taman Nasional Gunung Gede Pangrango jika kalah innovasi dengan berbagai tempat wisata sejenis di daerah Bogor. Ancaman dari lokasi-lokasi serupa juga bisa mengurangi pendapatan dan jumlah pengunjung.

Peneliti dan tim surveyor sendiri telah berdiskusi dan mempertimbangkan, roadmap untuk pengembangan Taman Nasional Gunung Gede Pangrango untuk menjadi Taman Wisata Nasional yang professional harus dimulai dari:

1. Pengelolaan Sumber Daya Manusia dan Manajemen harus ditingkatkan menjadi lebih professional dan baik. Pelatihan dan pengembangan harus diberikan kepada staff, karyawan dan seluruh jajaran pemimpin pengelola Taman Nasional ini. Agenda pertama yang harus dilakukan adalah peningkatan kompetensi untuk hospitality menjadi sangat penting.

2. Setelah kompetensi SDM menjadi baik, maka tim pengelola dapat mulai mengimplementasikan kompetensi pada pelaksanaan operasional Taman Nasional Gunung
Gede Pangrango. Dalam pelaksanaan harus ada control sheet yang minimal memantau dan mengevaluasi pelaksanaan standard yang telah dibuat untuk menjamin professionalitas dan baiknya hospitality bagi para pengunjung. Contoh pengukuran yang mungkin yaitu penggunaan seragam untuk karyawan dan pengelola, keramahan dan kepekaan harus ditingkatkan.

3. Selanjutnya adalah aspek inovasi yang harus digali dan ditemukan oleh tim pengelola dari internal. Tim peneliti dan surveyor sendiri memberikan saran dengan pemanfaatan beberapa tool manajemen seperti Business Model Canvas dapat banyak membantu mencari nilai (value) dari Taman Nasional Gunung Gede Pangrango. Dari tim peneliti, inovasi yang dilakukan dapat dengan membuat membership exclusive untuk pengunjung, lalu menerapkan sistem point dan achievement jika mereka berhasil mendaki lebih tinggi. Pengunjung dapat diberikan reward berupa trophy achievement yang bisa juga ditukarkan dengan hadiah. Atau bisa juga reward yang diberikan yaitu publikasi top hiker di website resmi Taman Nasional Gunung Gede Pangrango. Atau jika memang 
memungkinkan dikembangkan APPS khusus seputar Gunung Gede Pangarango dan menjadikannya sebuah Game untuk para pengunjung dengan pemanfaatan virtual reality. Tentunya semua saran ini hanya sebatas ide yang diharapkan bisa memberikan ide lain yang lebih bagus dan possible bagi para pengelola.

\section{KESIMPULAN}

Berdasarkan temuan di atas, maka tim peneliti menyimpulkan beberapa hal ini:

Dari sisi ketenagakerjaan, pihak manajemen perlu meningkatkan "Product Knowledge" dari para penjaga serta pegawai di lokasi wisata baik Taman Cibodas maupun Taman Nasional Gunung Gede Pangrango. Dengan meningkatkan Product Knowledge tersebut maka diharapkan para tenaga kerja dan karyawan mampu lebih baik dalam memberikan informasi kepada para pengunjung mengenai kawasan wisata tersebut. Selain itu hal ini juga menjadi salah satu sarana promosi untuk menarik tourist yang berkunjung.

Masih terkait dengan ketenagakerjaan ini, selain kurangnya "Product Knowledge" pihak pengelola juga harus mulai memikirkan pengembangan lebih jauh dari tim petugas di kawasan ini (Baik Taman Cibodas ataupun Taman Nasional Gunung Gede Pangarango). Pengembangan yang cukup penting dari sisi sumber daya manusia adalah pemanfaatan teknologi, social media yang bisa digunakan untuk sarana promosi yang lebih luas jangkauannya dan juga penerapan prinsip hospitality yang berguna untuk peningkatan kesigapan dan inisiatif petugas dalam melayani pengunjung. Dengan demikian diharapkan kenyamanan pengunjung dapat meningkat menjadi lebih baik.

Fasilitas dari Taman Cibodas dan Taman Nasional Gunung Gede Pangarango secara umum telah memiliki infrastruktur yang baik. Selain itu aksesibilitas juga sudah cukup baik. Pengelola sendiri telah membuat hiking trail yang cukup memadai sampai Air Terjun Cibeureum merupakan langkah sudah sangat baik bagi tim peneliti. Akan tetapi pada akhirnya Toilet juga merupakan fasilitas yang perlu ditingkatkan pada kedua tempat ini. Memang dalam pengelolaannya masih belum sempurna akan tetapi ada baiknya ada pembersihan secara berkala untuk meningkatkan kenyamanan bagi para pengunjung atau pendaki.

Tim peneliti, merasa penting sekali bagi desa, masyarakat dan pengelola mulai memiliki visi profesionalitas untuk membawa potensi wisata kedua lokasi ini. Langkah awal yang bisa dilakukan adalah pembentukan koperasi untuk pengelolaan uang dan pemberdayaan potensi ekonomi 
masyarakat lokal. Dengan adanya koperasi dan prinsip ekonomi kerakyatan maka tim pengelola dapat menghimpun dana sehingga dapat melakukan perbaikan dan pengembangan masyarakat dari sisi softskill seperti yang dijelaskan pada poin 1 dan 2. Dengan mengembangkan masyarakat sekitar, maka pihak pengelola juga telah berkontribusi untuk kesejahteraan masyarakat dengan membuka potensi bagi mereka untuk menjual service kepada pengunjung. Hal ini tentunya harus diatur secara baik dan profesional. Tim peneliti menyarankan pembentukan koperasi karena bentuk badan usaha ini cukup mudah untuk langsung dilaksanakan dan sifatnya adalah kebersamaan oleh sesama anggota koperasi. Dari pembentukan koperasi ini maka langkah selanjutnya adalah masyarakat dan pengelola bisa belajar untuk mengalokasikan uang ke kebutuhan yang lebih penting untuk pencapaian optimal dari Kawasan Wisata tersebut.

Beberapa indikator risiko yang overperform (Zona 4) bisa dijadikan prioritas terakhir dalam pengembangannya, sedangkan beberapa indikator risiko yang underperform harus segera ditingkatkan pengembangannya (Zona 2). Untuk indikator risiko yang telah sangat baik (Zona 1) pihak pengelola harus secara konsisten menjaga performanya, sedangkan untuk indikator risiko yang kurang begitu penting, dan juga performanya jelek (Zona 3) maka pihak manajemen juga perlu mengevaluasi jeleknya performanya karena apa akan tetapi tetap menjadi prioritas terakhir dalam pengembangan.

Innovasi pengelola adalah kunci strategi yang penting dalam pengembangan Potensi Kawasan Wisata ini. Innovasi pertama yang dibuat seperti naik gunung cantik bisa menjadi sebuah produk yang memiliki potensi jual sangat baik di mata masyarakat. Menurut tim peneliti hal ini memiliki nilai ekonomi yang baik, apalagi kalau bisa dijual kepada mahasiswa pecinta alam di Jakarta dan sekitarnya. Hal ini menjawab kebutuhan akan pasar yang suka untuk berpetualang di alam akan tetapi terbatas dari sisi perlengkapan. Program-program innovasi (produk) seperti ini yang harusnya secara konsisten dipikirkan dan dilaksanakan setiap tahun. Pihak pengelola setiap tahunnya harusnya memiliki pengembangan produk seperti ini sehingga tetap meningkatkan nilai jual kawasan Wisata Gunung Gede Pangarango ini.

Tantangan inovasi menjadi cukup penting, terutama untuk memastikan dan meningkatkan jumlah pengunjung. Penggunaan website dan apps bisa digunakan sebagai sarana Game Simulasi untuk meng-"induce" para pengunjung untuk tetap datang dan memiliki tujuan 
dan capaian ketika berkunjung ke Taman

Nasional Gunung Gede Pangrango.

\section{DAFTAR PUSTAKA}

Banks, Erik; Richard Dunn. (2003). Practical Risk Management.John Wiley \& Sons Ltd. Chichester

Belmont, David P. (2004). Value Added Risk Management in Financial Institutions, Leveraging Basel II \& Risk Adjusted Performance Measurement. John Wiley \& Sons. Singapore

\section{Bramantyo Djohanputro. (2004). Manajemen Risiko Korporat Terintegrasi, Memastikan Keamanan\&Kelanggengan Perusahaan Anda. Penerbit PPM. Jakarta}

Budhijono, Fongnawati \& Sugiarto. (2013). Struktur Kepemilikan Perusahaan, Permasalahan Keagenan, Corporate Governance dalam Perspektif Akuntansi Keperilakuan. Yayasan Pendidikan Wiyatamandala

Cadbury, A. 1992 The Cadbury Committee Report: Financial Aspects of Corporate Governance, Burgess Science Press, London.

Crouhy, Michel., Galai, Dan \& Mark, Robert. (2006). The Essentials of Risk Management. McGraw-Hill.

Dowd, Kevin. (2002). An Introduction to Market Risk Measurement. John Wiley \& Sons Ltd. Chichester

Dowd, Kevin. (1998). Beyond Value At Risk: The New Science of Risk Management. John Wiley \& Sons Ltd. Chichester
Ferry N. Idroes , Sugiarto. (2006). Manajemen Risiko Perbankan Dalam Konteks Kesepakatan Basel dan Peraturan Bank Indonesia. Penerbit Graha Ilmu. Yogyakarta

Galati, Reto R. (2003). Risk Management and Capital Adequacy. Mc GrawHill. New York

Gitman, Lawrence J., Zutter, Chad J. (2012). Principles of Managerial Finance. 13th ed. Pearson Education Limited. England

Global Association of Risk Professionals. (2006). Indonesia Certificate in Banking Risk and Regulation, Workbook Level 2. Global Association of Risk ProfessionalsBadan Sertifikasi Manajemen Risiko

Global Association of Risk Professionals. (2005). Indonesia Certificate in Banking Risk and Regulation, Workbook Level 1. Global Association of Risk ProfessionalsBadan Sertifikasi Manajemen Risiko

Kaen, Fred R. 2003 A Blueprint for Corporate Governance: Strategy Accountanbility, and the Preservation of Shareholder Value New York NY: American Management Association

Kusmayadi dan Sugiarto. (2000). Metodologi Penelitian bidang Pariwisata dan Hospitality. Gramedia Jakarta.

Kodiat, H. 1999. Identifikasi Potensi Ekotourisme Indonesia dan Prospek Pengembangannya. Kumpulan Makalah Seminar Prospek dan Manajemen Memasuki Millenium Ketiga. Departemen Kehutanan dan Perkebuanan Innovatif Development For Eco Awarneness. Bogor. Hlm 31- 37. 
Marshall, Christoper Lee. (2001). Measuring and Managing Operational Risks in Financial Institutions. John Wiley \& Sons (Asia) Pte Ltd. Singapore

Robertson, Doone; Kean, Ian \& Moore, Stewart. (2006). Manajemen Risiko Pariwisata. Asia-Pacific Economic Cooperation. APEC International Centre for Sustainable Tourism (AICST)

Shleifer, Andrei \& Vishny, Robert W. (1986).Large shareholders and corporate control.Journal of Political Economy, 94.461-488.
Shleifer, Andrei \& Vishny, Robert W. (1997).A survey of corporate governance.Journal of Finance, 52-2, 737-783.

Sugiarto \& Pradana, Bayu Laksma (2013). Esensi manajemen Keuangan perusahaan. Yayasan pendidikan Wiyatamandala

Santi Palupi \& Sugiarto (2014). Manajemen Risiko Hospitaliti \& Pariwisata.Yayasan Pendidikan Wiyatamandala

Undang - Undang RI No 10 tahun 2009 tentang Kepariwisataan 